\title{
Ammonia to Power: Forecasting the Levelized Cost of Electricity from Green Ammonia in Large-scale Power Plants
}

Authors: Zac Cesaro ${ }^{a}$, Matthew Ives ${ }^{b}$, Richard Nayak-Lukea, Mike Mason ${ }^{\text {a }}$, René Bañares-Alcántara ${ }^{\text {a* }}$

${ }^{a}$ University of Oxford, Department of Engineering Science, OX1 3PJ, Oxford, United Kingdom-UK

${ }^{b}$ University of Oxford, School of Geography and the Environment, OX1 3QY, Oxford, United Kingdom-UK

*Corresponding author: rene.banares@eng.ox.ac.uk.

\section{Abstract}

Green ammonia, synthesized from air, water, and renewable energy, is a carbon-free energy storage vector with numerous potential energy applications, including dispatchable green electricity for the power sector. Due to the low cost of storing and transporting ammonia, green ammonia can be available as an energy source in all geographies, without the geological storage requirements of carbon capture and storage (CCS) or underground hydrogen storage. Here we contribute a novel techno-economic analysis to forecast the levelized cost of electricity (LCOE) from ammonia based on near-term and longterm technological developments to 2040, thus filling the knowledge gap for the application of ammonia as an energy vector in the electricity sector. We find that green ammonia could be available in many locations for less than 400 USD/t in 2040 with potential to be reduced to below 300 USD/t if electrolyzers achieve optimistic cost reductions, or when more favorable renewable resources are used to supply a global green ammonia market. We model ammonia-to-power via combustion in combined cycle gas turbines (CCGT) as a promising route to low-cost, dispatchable electricity generation. At power plant capacity factors below $25 \%$, which may be increasingly common in electricity sectors with high variable renewable electricity, a tipping point occurs around $400 \mathrm{USD} / \mathrm{t}$ ammonia fuel price to enable green ammonia to compete with other prominent forms of dispatchable, low or zero-carbon technologies, such as gas, bio-energy, or coal fired power plants with post-combustion CCS.

Keywords: green ammonia, power generation, LCOE, ammonia cracking, gas turbine, Power-to-X 


\title{
Ammonia to Power: Forecasting the Levelized Cost of Electricity from Green Ammonia in Large-scale Power Plants
}

\author{
Authors: Zac Cesaro, Matthew Ives, Richard Nayak-Luke, Mike Mason, René Bañares-Alcántara
}

\begin{abstract}
Green ammonia, synthesized from air, water, and renewable energy, is a carbon-free energy storage vector with numerous potential energy applications, including dispatchable green electricity for the power sector. Due to the low cost of storing and transporting ammonia, green ammonia can be available as an energy source in all geographies, without the geological storage requirements of carbon capture and storage (CCS) or underground hydrogen storage. Here we contribute a novel techno-economic analysis to forecast the levelized cost of electricity (LCOE) from ammonia based on near-term and longterm technological developments to 2040, thus filling the knowledge gap for the application of ammonia as an energy vector in the electricity sector. We find that green ammonia could be available in many locations for less than $400 \mathrm{USD} / \mathrm{t}$ in 2040 with potential to be reduced to below $300 \mathrm{USD} / \mathrm{t}$ if electrolyzers achieve optimistic cost reductions, or when more favorable renewable resources are used to supply a global green ammonia market. We model ammonia-to-power via combustion in combined cycle gas turbines (CCGT) as a promising route to low-cost, dispatchable electricity generation. At power plant capacity factors below $25 \%$, which may be increasingly common in electricity sectors with high variable renewable electricity, a tipping point occurs around $400 \mathrm{USD} / \mathrm{t}$ ammonia fuel price to enable green ammonia to compete with other prominent forms of dispatchable, low or zero-carbon technologies, such as gas, bio-energy, or coal fired power plants with post-combustion CCS.
\end{abstract}

Keywords: green ammonia, power generation, LCOE, ammonia cracking, gas turbine, Power-to-X

\section{Introduction}

The electricity sector is responsible for nearly $40 \%$ of global carbon dioxide emissions today, with electricity demand predicted to grow by more than $50 \%$ by 2040 [1]. Forecasted electricity system models (ESM) predict a rapid uptake of variable renewable electricity (VRE) technologies, such as solar photovoltaics (PV) and wind, to decarbonize the electricity sector. Such scenarios have also identified the need for deploying balancing, dispatchable technology for reliable grid operation [1, 2, 3, 4]. Carbon capture, and storage (CCS), commonly associated with Bio-Energy and CCS (BECCS), is the most frequently cited methodology for dispatchable low-carbon electricity, with the International Energy Agency (IEA) forecasts including 5\% of global electricity generation in 2040 from assets with CCS [1]. Beyond CCS, there is interest in hydrogen firing in gas turbines, albeit with cost challenges of hydrogen storage and transport [2, 5]. Meanwhile, green ammonia's role as a low-cost energy vector for the power sector has been overlooked in all forecasting and capacity planning models $[1,4]$.

Interest in green ammonia as an energy vector is gaining momentum with its inclusion as a key technology for cross-sector decarbonization in recent reports from several international organizations $[5,6$, 7] as well as a focus of industry [8,9]. Research is ongoing in improved green ammonia synthesis from VRE $[10,11]$ as well as use for energy purposes [12, 13].

Green ammonia is relevant to investigate for electricity generation because it is an energy-dense fuel with few technical barriers to adoption, and there will likely be a large global supply chain of green ammonia in the future. The recent momentum in decarbonization of the shipping industry using green ammonia $[14,15$,
16] is an indicator of many of the advantages of ammonia that can be applied equally to large scale power generation, including scalability in production with declining costs, a relatively high energy density with simple storage requirements, safe use in industrial settings, and potential for being the lowest cost zerocarbon option. Forecasts for the role of ammonia as a shipping fuel range from $25 \%$ [17] to $99 \%$ [18] of global maritime fuel by 2050. Leading engine manufacturers are commencing with combustion development in their internal combustion engines (ICE) [9, 19]. Green methanol is another widely considered fuel for energy purposes such as shipping, but preliminary forecasts suggest green ammonia will be lower cost due to the high cost of direct air capture of $\mathrm{CO}_{2}[5,13]$.

The steps towards a global green ammonia supply chain are being driven by decarbonizing the large, already existing ammonia fertilizer supply chain [20], currently at 180 million tons per year [7], as well as the emerging energy uses, such as shipping [17] and hydrogen transport [21]. The shipping sector would require five times as much ammonia as the current global fertilizer industry by 2050 if it transitioned to $100 \%$ ammonia [18]. Production of industrial scale green ammonia is already being assessed for feasibility in Chile [22], New Zealand [23], Norway [20], Saudi Arabia [21], and four locations in Australia [24, 25, 26, 27] in anticipation of such large future markets. At such scales it is reasonable to assume that green ammonia would be available as an energy vector at most locations for electricity generation.

The levelized cost of ammonia (LCOA) is becoming more frequently modelled as green ammonia gains attention as an energy vector. Many models use general assumptions about the renewable electricity (RE) full load hours (FLH) and levelized cost of 
electricity (LCOE) to build a simple estimate of LCOA (e.g. 7,000 FLH at 18-21 USD/MWh for an LCOA of $225 \mathrm{USD} / \mathrm{t} \mathrm{NH}_{3}$ [15], 3,000 FLH at $25 \mathrm{USD} / \mathrm{MWh}$ for and LCOA of $350 \mathrm{USD} / \mathrm{t} \mathrm{NH}_{3}$ [5], and 8,000 FLH at $24 \mathrm{USD} / \mathrm{MWh}$ for an LCOA of $620 \mathrm{USD} / \mathrm{t} \mathrm{NH} 3$ [14]). However, these models are missing key plant components, such as substantial hydrogen storage and/or electricity storage needed to manage RE variability. There are several far more detailed models in the literature $[28,29,30,31]$ which demonstrate that to determine LCOA to a useful level of accuracy requires optimization to the process level based on the specific geographical wind and solar supply profile, local component costs, local financing costs, and synthesis plant flexibility, as found in [28]. These detailed models find LCOA for a specific site, rather than a broadly applicable LCOA forecast. In [28], this specificity is overcome by modelling LCOA at over 500 locations around the world. The results find that a range of $310-500 \mathrm{USD} / \mathrm{t}$ will be available in many locations around the world by 2030 [28]. However, this complex model and others are difficult to replicate, modify, and test for different input sensitivities. There is a knowledge gap in producing a geographically nonspecific LCOA forecast for the market, such as in [5, 15], that approaches the complexity and accuracy of complex models, such as [28]. Thus, a novel model of LCOA forecasting is developed in this paper that is applicable to many geographic regions, using only solar PV with night-time battery storage integration, and validated with the complex model in [32]. This novel model is simpler than that presented in [28], and thus enables the addition of new technologies such as solar PV with single axis tracking and battery storage, including a transparent sensitivity analysis. Finally, the novel model presented here provides more detailed and practical plant design than the prevalent simple models, such as in [5].

Technological progress in ammonia-to-power has been extensively reviewed by [12], with notable progress in direct ammonia fuel cells for transport [13], co-firing with coal [33], and firing in gas turbines [34]. Analyses from [5] and [35] suggest that ammonia may be the lowest cost method of international trade of hydrogen, specifically to Japan, when compared with liquid organic hydrogen carriers and liquified hydrogen. However, there is a knowledge gap in the techno-economic comparison of green ammonia-topower at power plant scale, especially compared with frontrunning low-carbon, dispatchable technologies such as fossil fuel with CCS, BECCS, and nuclear power. Moreover, the levelized cost of electricity (LCOE), the key indicator of economic competitiveness in the electricity sector, has not been calculated for near-term green ammonia-to-power technologies.

Therefore, the objectives of this paper are: (i) to forecast a widely available green ammonia LCOA from solar PV with highlighted sensitivities, (ii) to forecast a green ammonia-to-power levelized cost of electricity (LCOE) in the electricity sector, and (iii) to compare green ammonia to power at large scale with alternatives, including CCS and nuclear power to highlight scenarios where green ammonia may be competitive in the electricity sector in the future. The originality of this paper is in developing novel technoeconomic models of power-to-ammonia via solar PV and batteries, and ammonia-to-power via combined cycle gas turbines (CCGT), based on near-term and long-term technological developments. Additionally, by pairing these models in one analysis, a more detailed understanding of the full ammonia energy system's key sensitivities is presented.

\begin{tabular}{ll}
\multicolumn{1}{c}{ NOMENCLATURE } \\
\hline ASU & Air Separation Unit \\
BECCS & Bio-Energy with CCS \\
BNEF & Bloomberg New Energy Finance \\
CAPEX & Capital Expenditure \\
CCGT & Combined Cycle Gas Turbine \\
CCS & Carbon Capture and Storage \\
DEA & Danish Energy Agency \\
ESM & Electricity system model \\
FLH & Full Load Hours \\
GHI & Global Horizontal Irradiance \\
H2 & Hydrogen \\
HB & Haber-Bosch synthesis process \\
ICE & Internal Combustion Engines \\
IEA & International Energy Agency \\
IRENA & International Renewable Energy Agency \\
LCOA & Levelized cost of ammonia \\
LCOE & Levelized cost of electricity \\
LHV & Lower heating value \\
LNG & Liquefied Natural Gas \\
N2 & Nitrogen \\
NH3 & Ammonia \\
O\&M & Operations and Maintenance \\
PEM & Proton Exchange Membrane \\
PV & Photovoltaic \\
RE & Renewable Electricity \\
SMR & Steam Methane Reforming \\
TPD & (Metric) Ton Per Day \\
TRL & Technology Readiness Level \\
VRE & Variable Renewable Energy \\
WACC & Weighted Average Cost of Capital \\
& \\
\hline & \\
\hline
\end{tabular}

\section{Methodology}

\subsection{Green ammonia production costs}

The LCOA has been calculated for 2020-2040 to determine the realistic fuel cost of green ammonia and to highlight key sensitivities. To forecast the LCOA, the production cost of green ammonia was modelled using an industrial scale green ammonia synthesis plant, using solar PV as the energy source (Fig. 1). Full cost and performance assumptions are listed in Appendix A, with forecasted reductions to 2040.

The LCOA was calculated using a simplified method based on the methodology of [32] for "islanded" production, i.e. with no connection to the electricity grid. Islanded production is seen as 
favorable for green ammonia projects due to the improved renewable electricity (RE) resources in locations far from the grid as well as avoided grid connection costs [36]. At the scale of average ammonia plants (500 - 1,500 metric ton per day (TPD)), hundreds of MW of RE resources are required, and thus onsite generation is preferred to grid connection.

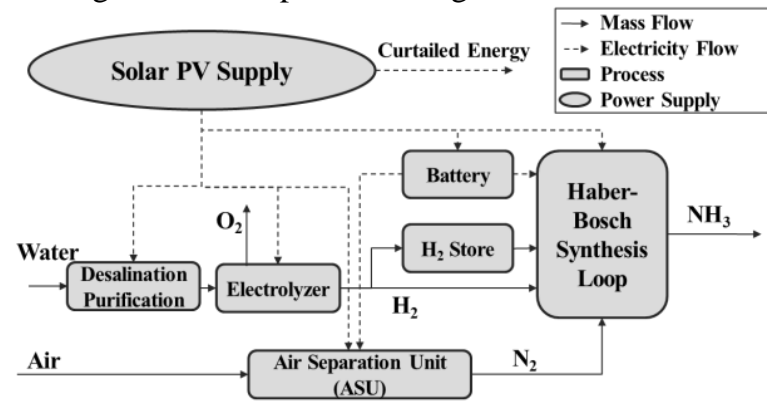

Fig. 1. Green ammonia synthesis process, based on [32]

In this model, techno-economic data is used for solar PV with single axis tracking. All equipment is sized using a binary daily profile (Fig. 2a), assuming that all of the required hydrogen is produced when solar electricity is available. Hydrogen is then stored in above ground hydrogen tanks at 200 bar to allow for a constant supply of hydrogen to the Haber-Bosch (HB) synthesis loop. The electricity requirement of the HB and air separation unit (ASU) is powered by battery storage when solar electricity is not available. This simplified approach has been validated with the model outlined in [32] when considering locations with only solar PV, with LCOA error of less than $10 \%$, given the same input assumptions (Fig. 2b). Thus, this simplified methodology provides an approximate yet reliable LCOA estimate with visibility to key sensitivities. A generic solar global horizontal irradiance (GHI) of $2,000 \mathrm{kWh} / \mathrm{m}^{2} /$ year is used in this analysis. This level of solar irradiation was chosen because it is widely available, including in parts the USA and Central America, South America, India, China, northern Africa, southern Africa, the Middle East, Australia, and southern Europe [37]. Single axis tracking solar PV systems are becoming increasingly common, accounting for nearly $70 \%$ of utility scale solar PV installations in the US in 2018 [38]. Using the assumptions listed in Appendix A, the achieved LCOE from single axis tracking solar PV is reduced from 28.5 USD/MWh in 2020 to $16.8 \mathrm{USD} / \mathrm{MWh}$ in 2040. Wind and wind/solar hybrid plants were not considered in this analysis, as they would require more complex LCOA methodology as in [32]. Additionally, solar PV has a lower long-term LCOE forecast [1].

The key challenge in green ammonia plant design is the limited flexibility of the HB synthesis loop, which is unable to mirror the incoming VRE profile [32]. In a first instance, hydrogen storage can mitigate the HB flexibility requirements. However, new HB technology will likely have increased flexibility to reduce the need for hydrogen storage, and thus reduce costs [28]. Some methods for reducing the minimum

a.
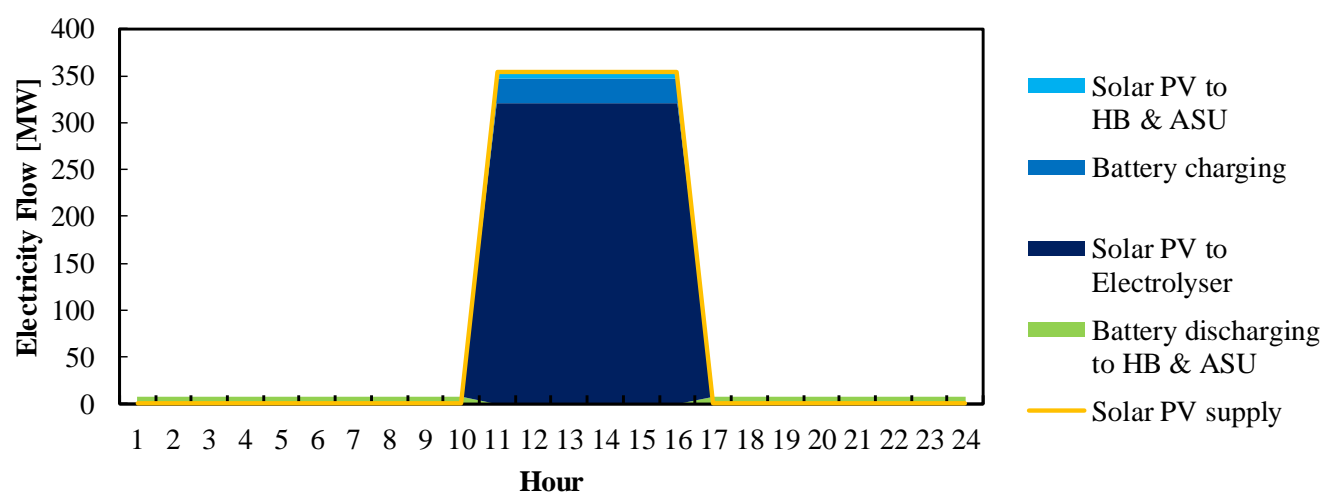

b.

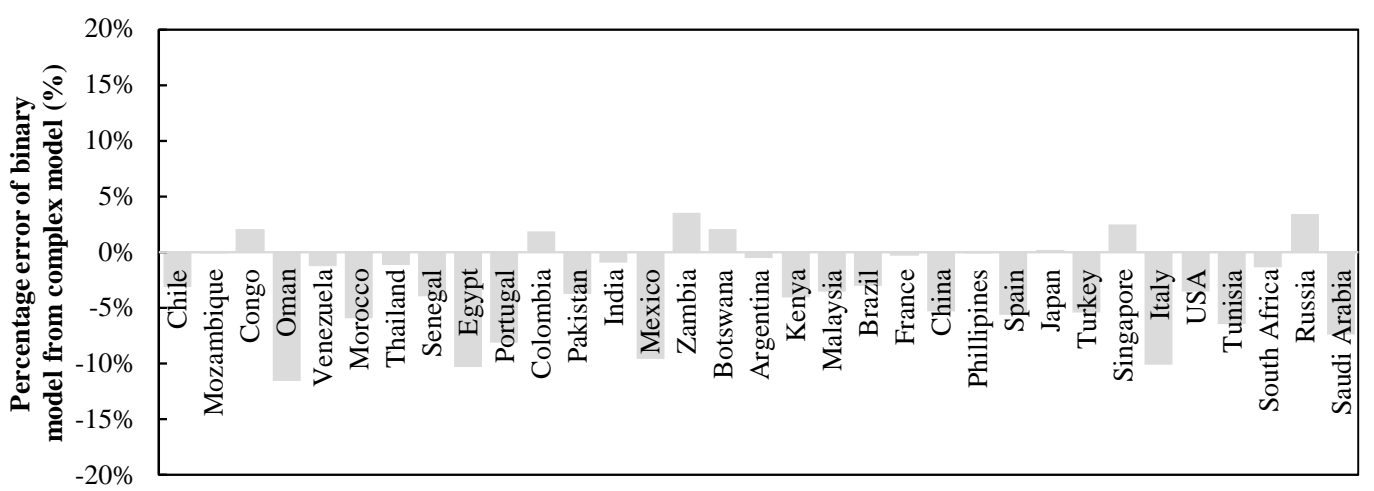

Fig. 2. a. Power allocation for $10 \mathrm{t} \mathrm{NH}_{3} / \mathrm{hr}$ green ammonia synthesis plant using simplified, binary methodology for plant equipment sizing. b. LCOA percentage error between simplified LCOA methodology and methodology used in [32] at 33 locations using solar PV with single axis tracking. 
load of the HB to $10-20 \%$ or rated capacity include reducing the purge rate and increasing the fraction of inert gases in the reactor [39]. Other computational research suggests a minimum of $33 \%$ of nameplate capacity can be achieved by varying both the inert gas fraction and the $\mathrm{H}_{2} / \mathrm{N}_{2}$ ratio [11]. In this analysis, the assumption of two days of hydrogen storage in 2020 was reduced to one day of hydrogen storage in 2040 , which is achievable based on modelling of plants with high HB flexibility of $20 \%$ minimum load [29].

LCOA was calculated using Eqn 1. [28]

$$
\operatorname{LCOA}=\frac{\sum_{\mathrm{t}=0}^{\mathrm{n}} \frac{\mathrm{C}_{\mathrm{t}}+\mathrm{O} \& \mathrm{M}_{\mathrm{t}}}{(1+\mathrm{r})^{\mathrm{t}}}}{\sum_{\mathrm{t}=0}^{\mathrm{n}} \frac{\mathrm{A}_{\mathrm{t}}}{(1+\mathrm{r})^{\mathrm{t}}}}
$$

Where

$\mathrm{C}_{\mathrm{t}}=$ Investment expenditures in year $\mathrm{t}$

$\mathrm{A}_{\mathrm{t}}=$ Ammonia produced in year $\mathrm{t}$

$O \& \mathrm{M}_{\mathrm{t}}=$ Operations and maintenance expenditures in the year $\mathrm{t}$

$\mathrm{n}=$ economic lifetime of the plant

$\mathrm{r}=$ Weighted average cost of capital (WACC)

\subsection{Ammonia to power costs}

Ammonia and the hydrogen contained within ammonia can be transformed into electricity via thermochemical routes (turbines or engines) or electrochemical routes (fuel cells). Additionally, ammonia can be decomposed or "cracked" back into $\mathrm{H}_{2}$ and $\mathrm{N}_{2}$ via thermal decomposition in the presence of a catalyst (Eqn 2) to feed hydrogen compatible power generation equipment, such as hydrogen fuel cells.

$$
2 \mathrm{NH}_{3} \rightarrow 3 \mathrm{H}_{2}+\mathrm{N}_{2} \Delta \mathrm{H}=92 \mathrm{~kJ} / \mathrm{mol} \quad(\text { Eqn 2) }
$$

An ammonia-to-power combined cycle gas turbine (CCGT) system was selected for lowest possible LCOE at power plant scale (100's of MW) based on cost and high technology readiness level (TRL) technology. Other technologies considered included fuel cells and co-firing with coal. While the technology for direct ammonia fuel cells is being researched [13] and demonstrated [40] at small scale for transport sector applications, the costs projections are unknown and likely cannot compete for some time with gas turbines at such large scales. Capital cost is the most important factor to consider because the efficiency gains of fuel cells are of little advantage when comparing with $60 \%$ efficient CCGT systems. The economic advantage of any efficiency gain is minimal due to the low annual fuel consumption of a plant at the low utilization rates projected, whereas the capital cost disadvantage is significant at low utilization. Similarly, ammonia cracking paired with hydrogen fuel cells was excluded from this analysis because of high capital cost of PEM fuel cells and high footprint of alkaline fuel cells at 100's of MW scale [41], and thus high cost. Finally, ammonia powered CCGT has lower projected costs than co-firing ammonia with coal for steam turbine power generation due to the high emissions of coal co-firing [42].

\subsubsection{Ammonia CCGT System Overview}

Ammonia-fueled CCGT systems can combust hydrogen derived from ammonia [43], or a blend of ammonia and hydrogen [34], or ammonia directly. This paper's analysis predicts that combustion technologies will progress over time from pure hydrogen (Phase 1), to blends of hydrogen and ammonia (Phase 2), to pure ammonia (Phase 3), in line with current industry research and development, and progress towards lower LCOE.

Phase 1: In industry, most CCGT manufacturers have committed to a $100 \% \mathrm{H}_{2}$ firing capability by 2030 [46]. Small scale $100 \%$ firing has been announced by Siemens for 12 MW by 2023 [47] and the first commercial project has been announced by Mitsubishi Hitachi Power Systems for $840 \mathrm{MW}$ of hydrogen compatible gas turbines operating at $30 \% \mathrm{H}_{2}$ in 2025 and $100 \% \mathrm{H}_{2}$ by 2045 [48]. To address the difficulty of storing GWh of hydrogen, the Mitsubishi project will utilize a very large underground salt cavern for hydrogen storage, which is conveniently available near the site in Utah, USA [48]. Some technical challenges with hydrogen compatibility include auto-ignition flashback, thermoacoustic effects, higher flame temperature and resulting $\mathrm{NO}_{\mathrm{x}}$ emissions, and challenges in designing for full flexibility from $100 \%$ natural gas to $100 \%$ hydrogen in one turbine (e.g. hydrogen requires significantly larger pipe sizes to handle the increased flow rate of volume to the turbine to deliver the same power) [49]. This last point is particularly challenging if turbines are connected to the natural gas transmission grid, and thus need to accommodate a fuel mix that may change several times over the coming decades.

Phase 2: Recent research into ammonia combustion has focused on exploring fuel blends to provide greater combustion stability, as well as emissions control of $\mathrm{NO}_{x}$ and unburned $\mathrm{NH}_{3}$ than pure ammonia combustion [34]. In particular, $70 \% \mathrm{NH}_{3} / 30 \% \mathrm{H}_{2}$ by volume has shown the best stability and performance in gas turbine research [34]. As early evidence of this technology, the world's first demonstrator of the full power-to-ammonia-to-power cycle at Rutherford Appleton Laboratory in Oxfordshire, UK uses a blend of $70 \% \mathrm{NH}_{3} / 30 \% \mathrm{H}_{2}$ by volume to achieve stability in a reciprocating engine designed for combustion on natural gas [8]. Furthermore, steam injection techniques show early promise for controlling $\mathrm{NO}_{\mathrm{x}}$ emissions in these blends without sacrificing fuel efficiency [50].

While the exact ratio may be subject to further research and development, dual-fueled engines are a promising route for easier engine re-design, as demonstrated in ICE engine development in the shipping industry which is using dual-fueled ammonia engines to enable near-term implementation [9].

Other blend research includes ammonia / methane blends [51], which may enable a variation of Phase 2 to be adopted in parallel with Phase 1 , albeit with some carbon emissions. 


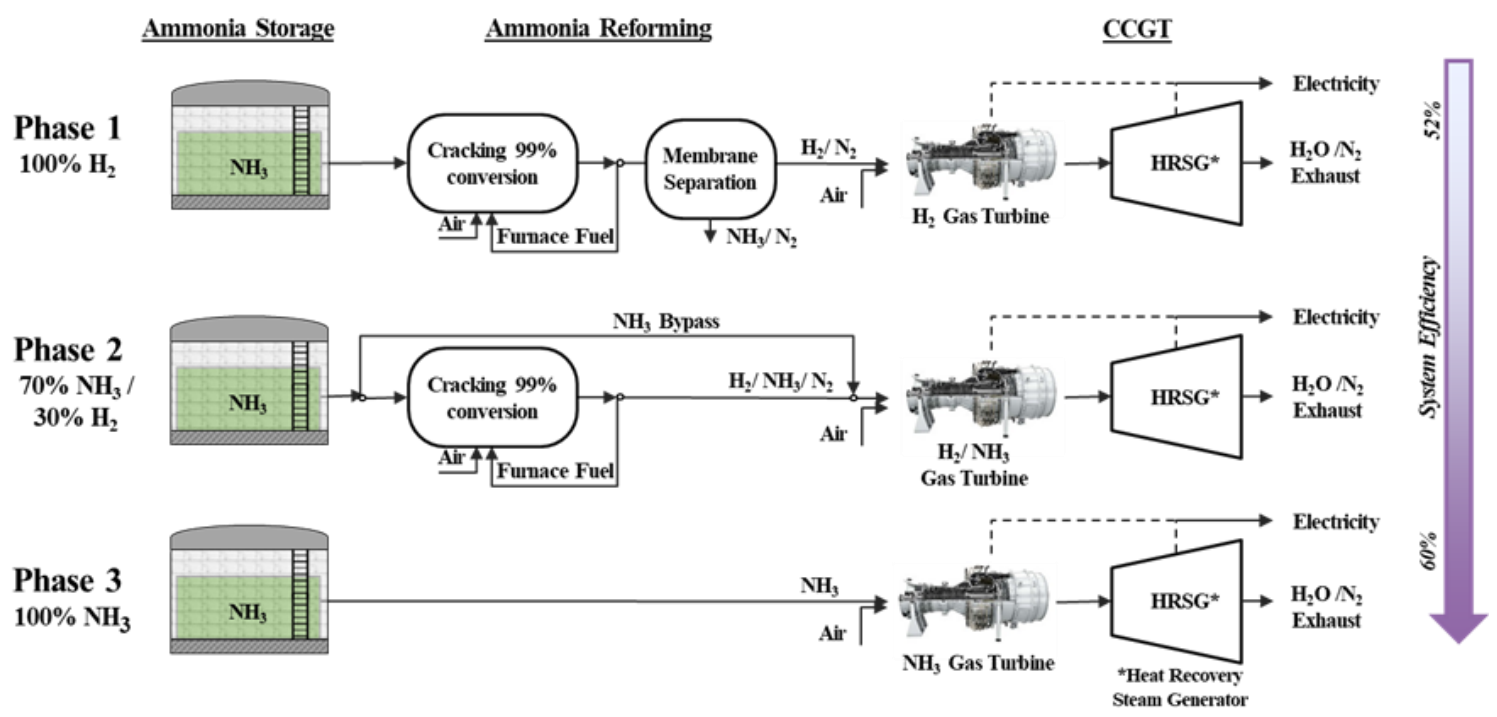

Fig. 3. AMMONIA-TO-POWER: Ammonia fuelled CCGT configurations as modelled in three cases of $100 \% \mathrm{H}_{2}, 70 \% \mathrm{NH}_{3} / 30 \% \mathrm{H}_{2}$, and $100 \% \mathrm{NH}_{3}$. Additional model details provided in Appendix B.

Phase 3: Finally, Phase 3 technology will utilize ammonia directly. Pure ammonia has several challenging properties related to combustion, including high auto-ignition temperature and low flame speed [12]. This technology is still in the research stage, with a small scale $50 \mathrm{~kW}$ micro gas turbine recently demonstrated on $100 \% \mathrm{NH}_{3}$ in Japan [45], with further research into pure combustion techniques ongoing, such as recent work in cyclonic burners [52].

\subsubsection{Ammonia Cracker Costs}

Forecasting the LCOE of Phase 1 and 2 requires a techno-economic analysis of an integrated ammonia decomposition system with CCGT.

The heat required for the high temperature thermocatalytic reforming in the system can be generated by cannibalizing a fraction of the decomposed product stream and burning this hydrogen rich stream in a fired reformer. This approach is similar to the one reported in [44] and is depicted in Phase 1 of Fig. 3. In a fully heat-integrated process, liquid $\mathrm{NH}_{3}$ would be vaporized and preheated using the low-grade heat of the exhaust stream. The integrated system in Phases 1 and 2 were modelled in ASPEN Plus to determine the heat integration, required rate of cannibalization, and overall system ammonia-to-power efficiency (Appendix B). The system CCGT was based on Siemens SGT-800, a medium (62.5 MW) turbine already capable of running on $50 \% \mathrm{H}_{2}$ [53]. In the modelled reformer, $99 \%$ conversion was assumed at $850^{\circ} \mathrm{C}$. This conversion and temperature assumption was based on small-scale commercial ammonia decomposition reactors, which use nickel catalysts at $850{ }^{\circ} \mathrm{C}[54,55]$. Literature suggests high conversion cracking is achievable between $650{ }^{\circ} \mathrm{C}$ and $900{ }^{\circ} \mathrm{C}$ depending on the catalyst [56]; however, for low cost and high technological maturity, nickel catalyst has been found to be the most cost-effective catalyst [57].
The technology for ammonia cracking is commercially available at small scale (i.e. less than 100 $\mathrm{kg} \mathrm{H}_{2} / \mathrm{hr}$ output) $[58,54,55]$. Large scale cracking can be modelled using steam methane reforming (SMR) as a basis, due to the analogous thermocatalytic cracking reactor design employed. Large-scale, thermocatalytic reformers for SMR are large fireboxes with dimensions at the scale of a building [59], with substantial economies of scale (Fig. 4). In a large scale cracker, ammonia would be fed through parallel, vertical, catalyst filled tubes, which are arranged in the firebox [60]. The design would closely resemble SMR because both processes are constrained by maintaining high enough reaction temperature inside the tubes against the endothermic cracking reaction $\left(\Delta \mathrm{H}=31 \mathrm{~kJ} / \mathrm{mol} \mathrm{H}_{2}\right.$ in $\mathrm{NH}_{3}$ decomposition versus a slightly higher SMR $\Delta \mathrm{H}=41-69 \mathrm{~kJ} / \mathrm{mol} \mathrm{H}_{2}$ ). This design constraint is managed through the design of the tube diameter and firebox temperature.

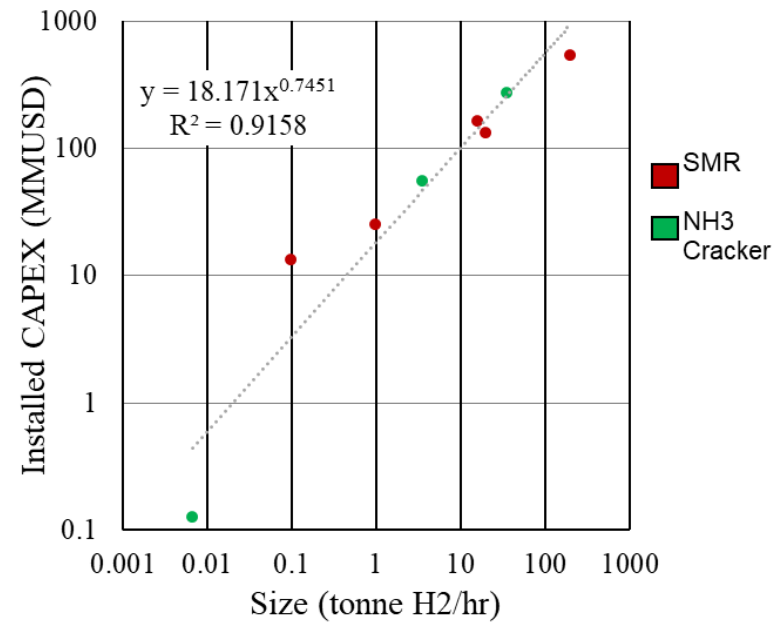

Fig. 4. CRACKER COST CURVE: Ammonia Reformer Installed CAPEX cost curve based on literature values for ammonia crackers at 0.007 [61], 3.6 and 36 ton $\mathrm{H}_{2} / \mathrm{hr}$ [43] and SMR at 0.10, 1.0, 20, 200 ton $\mathrm{H}_{2} / \mathrm{hr}$ [62], and SMR at 15.8 ton $\mathrm{H}_{2} / \mathrm{hr}$ [63]. 


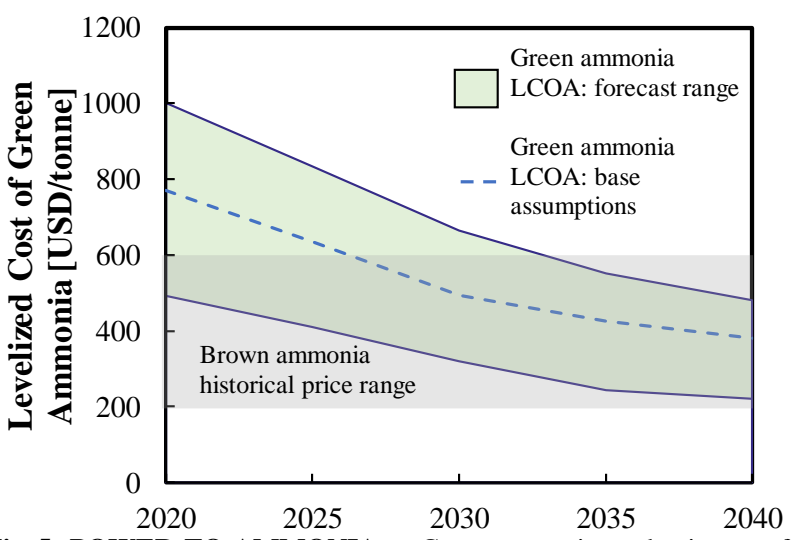

b

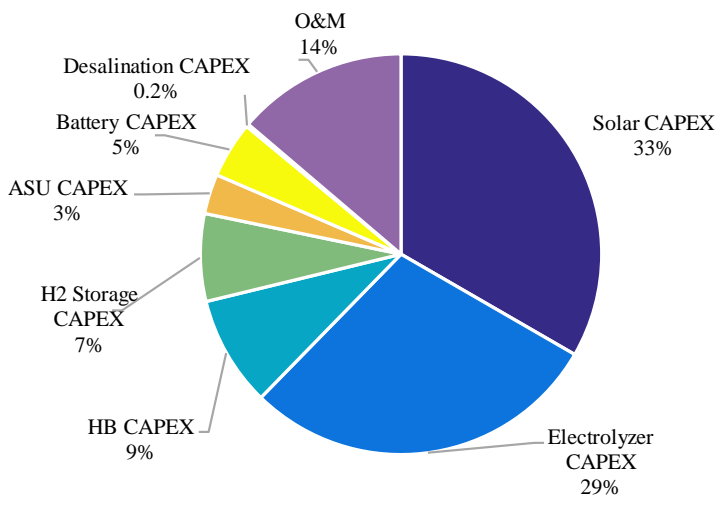

Fig. 5. POWER-TO-AMMONIA: a. Green ammonia production cost forecasted 2020 to 2040 with historical fossil fuel based ammonia price range of $200-600 \mathrm{USD} / \mathrm{t}$ [86]. LCOA range calculated using low and high literature estimates for electrolyzer CAPEX, WACC, and solar PV LCOE, as presented in Table 1. b. LCOA cost breakdown for 2040, base assumptions (Appendix A).

In Phase 1, the cannibalization stream was calculated to be $20.5 \%$ of the product stream using an ASPEN model of the system (Appendix B). Due to this fuel cannibalization in the pre-treatment cracking stage, overall fuel efficiency (based on the LHV of ammonia) was thus reduced to $52.5 \%$ from the base $60 \%$ CCGT efficiency [53]. Phase 2 has a fuel efficiency of $57.4 \%$, using a scaled model of Phase 1 , with most of the ammonia bypassing the efficiency losses in the cracking stage. For Phase 3, the baseline CCGT fuel efficiency is expected to be around $60 \%$.

The ammonia reformer was the only additional CAPEX considered for an ammonia CCGT system compared to a natural gas CCGT system. Costs for ammonia storage tanks were disregarded in this analysis because they were assumed to be the same cost as LNG. Due to the overlapping properties, some storage tanks for LNG can even be used for the storage of ammonia [64]. Therefore, the estimated increase in CCGT installed CAPEX for ammonia was based solely on the addition of an ammonia reformer.

\subsection{LCOE Methodology}

The LCOE can be broken down into component costs for fuel, installed CAPEX, operations and maintenance (O\&M), and emissions. Technoeconomic data for supercritical pulverized coal power plants with CCS, natural gas CCGT with CCS, nuclear, bio-energy with CCS (BECCS), and the three phases of ammonia CCGT shown in Fig. 3 are summarized in Appendix C. The LCOE for each Phase was calculated using Eqn 3. [65]

$$
\mathrm{LCOE}=\frac{\sum_{\mathrm{t}=0}^{\mathrm{n}} \frac{\mathrm{C}_{\mathrm{t}}+\mathrm{O} \& \mathrm{M}_{\mathrm{t}}}{(1+\mathrm{r})^{\mathrm{t}}}}{\sum_{\mathrm{t}=0}^{\mathrm{n}} \frac{\mathrm{E}_{\mathrm{t}}}{(1+\mathrm{r})^{\mathrm{t}}}} \quad \text { (Eqn 3) }
$$

Where

$\mathrm{C}_{\mathrm{t}}=$ Investment expenditures in year $\mathrm{t}$

$\mathrm{E}_{\mathrm{t}}=$ Electricity produced in year $\mathrm{t}$

$\mathrm{O} \& \mathrm{M}_{\mathrm{t}}=$ Operations and maintenance expenditures in year $\mathrm{t}$

$\mathrm{n}=$ economic lifetime of the plant

$\mathrm{r}=$ Weighted average cost of capital (WACC)

\section{Results and Discussion}

\subsection{Ammonia fuel price}

Green ammonia LCOA modelled from solar PV based on assumptions listed in Appendix A will reach 380 USD/t NH$~_{3}$ by 2040 (Fig. 5a). The key cost components are the electrolyzer CAPEX and the solar PV CAPEX. The key sensitivities assessed for LCOA were the electrolyzer CAPEX, the weighted average cost of capital (WACC) to finance the investment, the RE LCOE, and the RE full load hours (FLH), as shown in Fig. 6. Table 1 highlights low and high estimates for each key sensitivity in 2040, as found in the literature, and the combined effect of electrolyzer CAPEX, WACC, and solar PV LCOE on the LCOA. The uncertainty in these three variables is used to calculate the range depicted in Fig. 5a. The LCOA is more sensitive to the lower literature estimates, especially for the electrolyzer CAPEX and the RE full load hours.

\subsubsection{Sensitivity: Electrolyzer CAPEX}

The CAPEX for electrolyzers is very uncertain; however, this uncertainty will likely be resolved in the coming years as more projects are commissioned, and a clear experience curve is derived for the technology. Electrolyzer experience curves are likely the most accurate method for forecasting costs, based on those developed for other RE technologies such as wind and solar PV, which follow very reliable cost reduction rates based on installed capacity, i.e. learning rates [66, 67]. However, PEM electrolyzers do not have enough data and alkaline electrolyzers do not show a reliable learning rate when looking at historical data [68]. For alkaline electrolyzers, it is difficult to accurately calculate a learning rate at this point due to i) a wide CAPEX spread in the available data, ii) a lack of clarity in the data as to which components are included in CAPEX (e.g. compressors, gas rectifiers, storage tanks, balance of plant, engineering, etc.), and iii) confounding effects of project scale downsizing from large systems since 1990 due to the introduction of SMR for large scale hydrogen users [68]. 
Table 1: LCOA Sensitivity assumptions

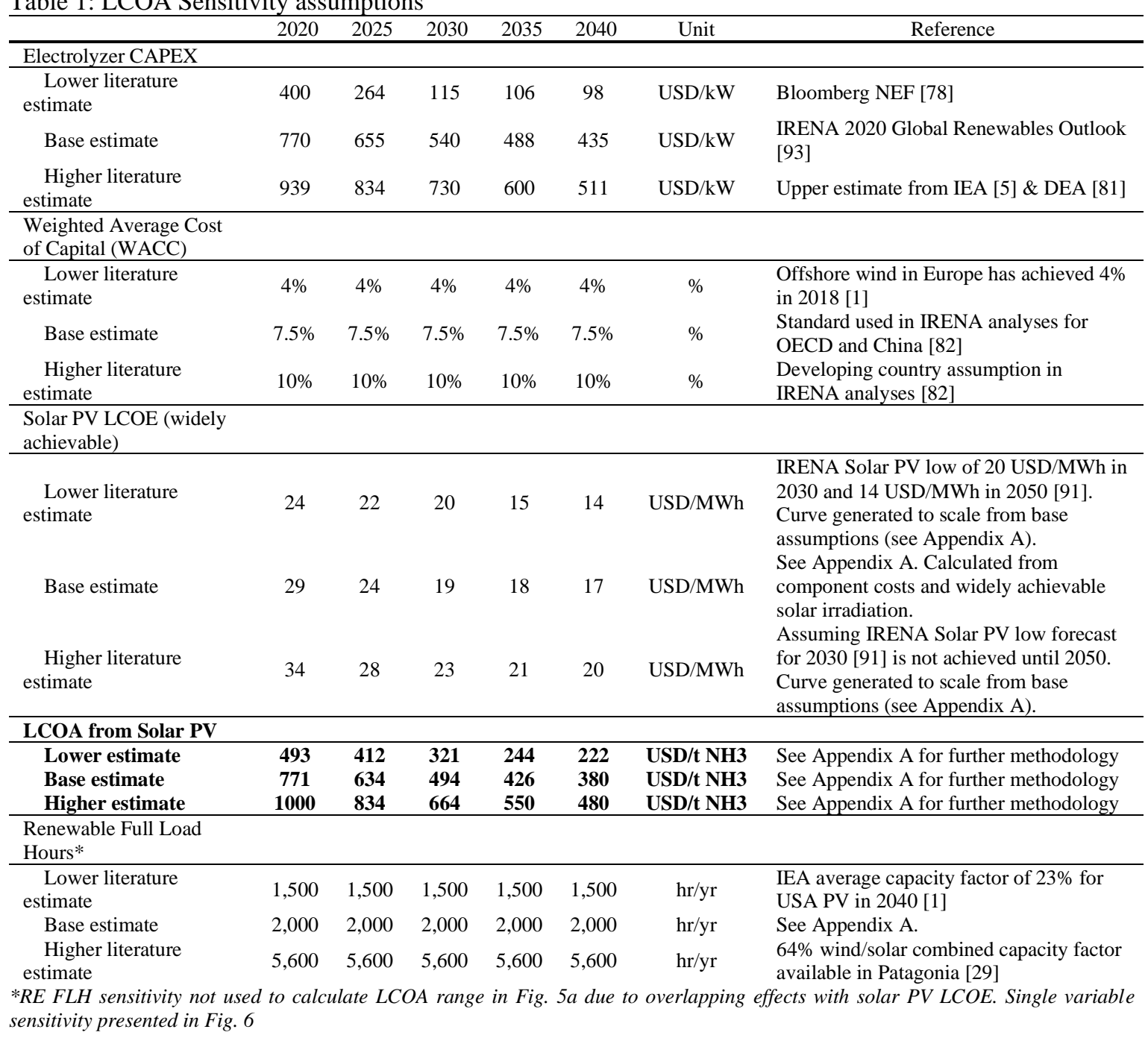

While the historical experience curve is difficult to determine, the future curve should be clear in the coming years. Electrolyzers have huge predicted growth, with IRENA predicting $1,700 \mathrm{GW}$ world capacity by 2050 [2], which requires $33 \%$ annual installation growth from the current installed capacity of $253 \mathrm{MW}$ in 2019 [69]. Already, the current pipeline of electrolyzer projects for completion in the mid2020 s is over $8 \mathrm{GW}$ [70].

\subsubsection{Sensitivity: Renewable Full Load Hours}

The other notable sensitivity for the LCOE calculations is the RE FLH, which could be increased significantly in regions with more favorable solar PV and wind resources. For example, the average FLH for offshore wind in Europe is projected to be over 5,100 hours in 2040 [1]. Hybrid wind and solar PV plants may be the most cost effective methods of achieving higher FLH, with analysis of green ammonia plant design in Chile and Argentina modelling over 5,600 combined FLH [29]. However, increasing RE FLH may also increase the RE LCOE, in the example of wind, or increase the transport costs, in the example of producing ammonia in favorable regions, such as Chile, and exporting it to regions with less favorable RE resources. Additionally, these high FLH locations may be prioritized for other purposes, such as synthetic fuel production for aviation.

The average of all the lowest sensitivity estimates and all the highest sensitivity values is $294 \mathrm{USD} / \mathrm{t}$ and $450 \mathrm{USD} / \mathrm{t}$, respectively. Importantly, the effects of the sensitivities are non-additive. For example, high RE FLH has a very favorable effect on LCOA but would have almost a $50 \%$ smaller effect if the electrolyzer CAPEX was at the lowest literature value of 98 $\mathrm{USD} / \mathrm{kW}$.

Interestingly, an LCOA below 200 USD/t can be achieved at an electrolyzer CAPEX of $98 \mathrm{USD} / \mathrm{kW}$ and WACC of $4 \%$. This would likely be a game-changing LCOA for many sectors, including the power sector. This sensitivity analysis highlights the potential for green ammonia to be an extremely cheap fuel in the 
long term, given the right techno-economic developments.

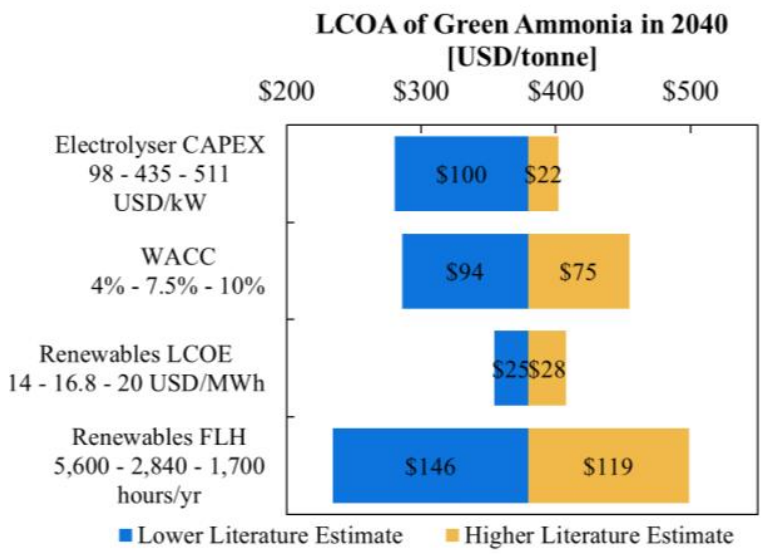

Fig. 6. Sensitivity analysis of LCOA in 2040 based on low and high values from literature for key model inputs. See Table 1.

\subsection{Green ammonia levelized cost of electricity (LCOE)}

The resulting average LCOE for each of the Phases for green ammonia-to-electricity are shown in Fig. 7Error! Reference source not found.a. Compared to other prominent low-carbon options, green ammonia is most competitive at low power plant capacity factors, specifically below $25 \%$ (Fig. 7b). While capacity factors above $50 \%$ are common today for dispatchable electricity generation [1], projections into the future suggest much lower capacity factors. For example, the IEA identified capacity factors as low as $15 \%$ for peaking gas turbines in future energy systems [5] and BNEF identified $25 \%$ as an approximate capacity factor required for dispatchable generation in scenarios compatible with $2^{\circ} \mathrm{C}$ decarbonization [4].

Based on the assumptions listed in Appendix C, ammonia direct firing in CCGT (i.e. Phase 3 technology) has an LCOE of 167 USD/MWh at a $25 \%$ power plant capacity factor, with the only lower LCOE generated in gas CCGT with CCS using future cost assumptions (30\% reduced in CAPEX and OPEX from 2020 to 2040 [71]).

The key sensitivities considered for green ammonia's LCOE are the fuel price, the WACC, the power plant capacity factor, and the $\mathrm{NH}_{3}$ firing compatibility (i.e. Phase 1,2 , or 3 ammonia CCGT technology). Table 2 highlights low and high estimates for each component in 2040, as found in literature, and Fig. 8 shows the LCOE sensitivity. The LCOE is most sensitive to the fuel price estimates and power plant capacity factor. Green ammonia fuel price, i.e. LCOA, is subject to wide uncertainty, with more potential on the lower end, as shown in Fig. 6.

Fig. 7 and Fig. 8 also highlight the cost difference in the three phases of ammonia CCGT technology (i.e. $\mathrm{NH}_{3}$ compatibility). Phases 2 and 3 have $10 \%$ and $15 \%$ lower LCOE than Phase 1, respectively. These results highlight the value for CCGT manufacturers to pursue pure ammonia combustion.

\subsubsection{Comparing ammonia CCGT with CCS}

CCS is the dominant low-carbon, dispatchable technology used in energy systems models, with over $400 \mathrm{GW}$ of fossil fuel with CCS deployed by 2050 in the latest IEA forecasts [1]. However, the results of this analysis suggest that green ammonia firing in CCGT may achieve lower costs by 2040 , or at least will be very competitive, and therefore should be included in prominent models.

In addition to fossil fuel combustion with $\mathrm{CCS}$, bioenergy with CCS (BECCS) is a widely discussed concept for employing net negative $\mathrm{CO}_{2}$ emissions. The results suggest that ammonia to power is over $20 \%$ lower cost at low plant capacity factors. Furthermore, there is uncertainty in the negative emissions provided based on land-use change, fuel transport costs, and the energy required to grow biomass $[72,73]$. There are also uncertainties in the biomass available for BECCS [73] as well as other sectors looking to use biogenic sources, such as aviation fuel.

Green ammonia enjoys several important advantages over CCS-based alternatives beyond LCOE. Firstly, green ammonia is geographically independent with low transport costs and high likelihood to be available in all ports if it becomes widely used in the shipping sector. CCS requires nearby underground storage or expensive $\mathrm{CO}_{2}$ transport to suitable underground storage locations. Secondly, ammonia CCGT can easily scale down to tens of MW, providing useful balancing services to a more decentralized grid of the future. Both nuclear and $\mathrm{CCS}$, on the other hand, are often considered at only GW scales [1]. Thirdly, upfront capital costs for ammonia CCGT are substantially lower. Ammonia CCGT electricity production is dominated by fuel costs, while CCS-based electricity is dominated by CAPEX (Fig. 7a). Per kW installed, ammonia CCGT adds $402 \mathrm{USD} / \mathrm{kW}$ in Phase 1 , while CCS adds 1,116 $\mathrm{USD} / \mathrm{kW}$ for gas CCGT and $1,426 \mathrm{USD} / \mathrm{kW}$ for supercritical coal (Appendix C). The first commercial CCS projects are forecasted to cost around 1 billion USD and take more than five years to design and build [1]. The smaller scale potential of ammonia CCGT favors more projects, sooner, and thus higher potential for cost reductions from experience curves [67]. Finally, CCS technologies are at best $90-95 \%$ effective at capturing emissions [74], while ammonia CCGT is fundamentally carbon-free (although other greenhouse gas emissions, such as $\mathrm{NO}_{\mathrm{x}}$, will need to be controlled). 
$\mathbf{a}$

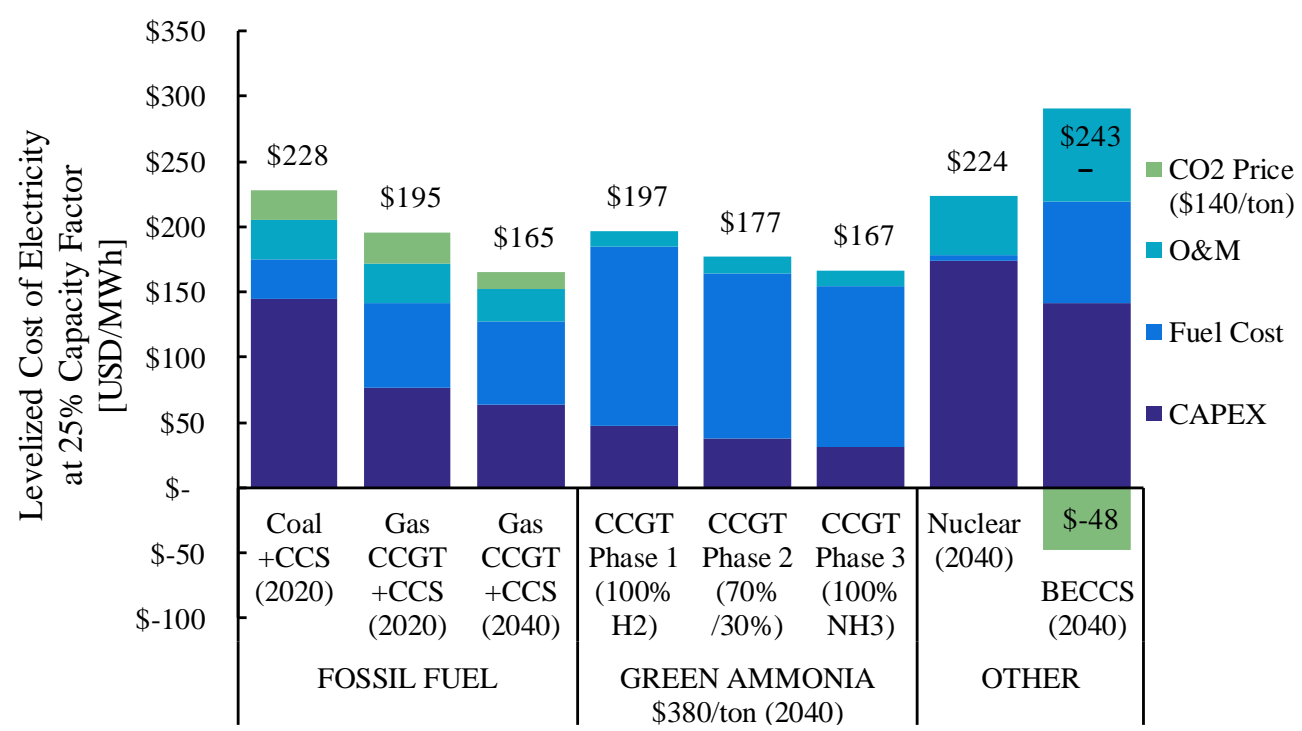

b

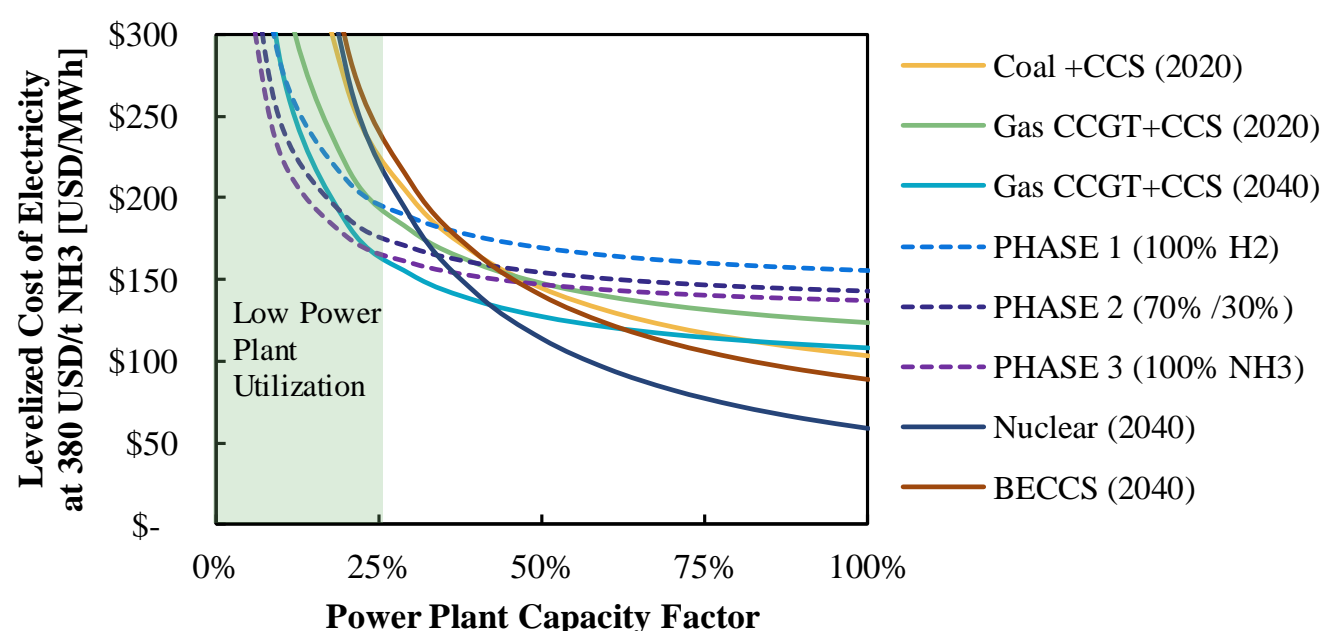

Fig. 7. a. LCOE comparison of low/no carbon dispatchable electricity using EU electricity sector assumptions at $25 \%$ power plant capacity factor based on BNEF forecasts in high VRE penetration scenarios [4]. b. LCOE of low/no carbon dispatchable electricity at a range of power plant capacity factors.

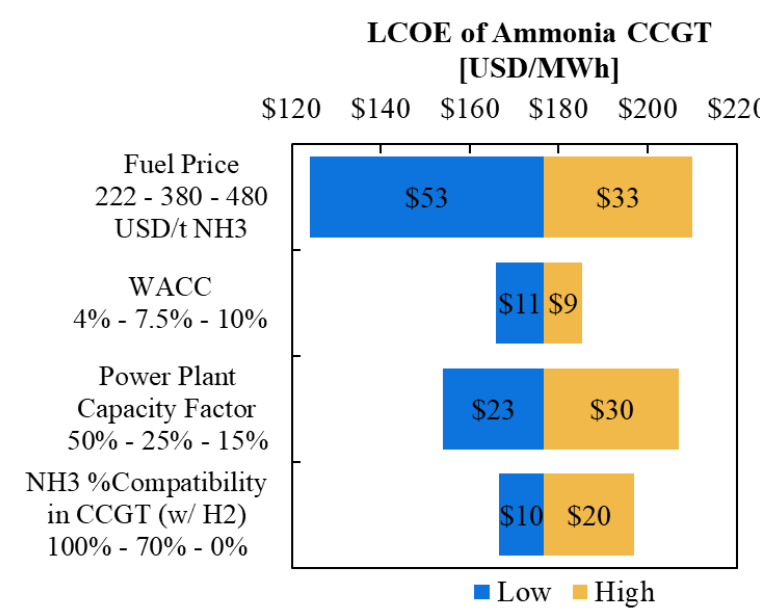

Fig. 8. Sensitivity analysis of LCOE in 2040 based on low and high values for key model inputs

\section{Conclusions}

Green ammonia is a technically viable and economically competitive fuel for decarbonization of the electricity sector via high efficiency gas turbine power plants by 2040. The levelized cost of electricity from green ammonia is forecasted to be $167-197$ USD/MWh at $25 \%$ power plant capacity factor in 2040 , assuming a widely available green ammonia fuel price of $380 \mathrm{USD} / \mathrm{t}$. This cost of electricity is comparable with natural gas power plants with post-combustion $\mathrm{CCS}$ and is significantly lower than coal with CCS, bioenergy with CCS, and nuclear power. The additional costs of $30 \mathrm{USD} / \mathrm{MWh}$ associated with cracking ammonia to fuel hydrogen fired gas turbines suggests that gas turbine manufacturers should prioritize achieving a more ammonia compatible turbine technology in the long term.

Currently, there are large uncertainties in the production cost of green ammonia, primarily due to a wide range of forecasts and lack of reliable experience 
curve data for electrolyzer capital cost. This uncertainty should be reduced substantially in the coming years as more large scale electrolyzer projects are deployed. A similar sized uncertainty is present in the cost of capital, which may depend on economic and political factors. Our estimates for the levelized cost forecast of green ammonia in 2040 ranges from $222 \mathrm{USD} / \mathrm{t}$ to $480 \mathrm{USD} / \mathrm{t}$ due to a range of assumptions on electrolyzer costs, cost of capital, and widely achievable solar PV costs.

While the levelized cost of electricity is a useful indicator of economic competitiveness, it is only when it is integrated into a national grid that the true economic competitiveness of green ammonia can be understood. In particular, specific grids require different capacity utilization rates of dispatchable energy sources [3] and have different available fuel prices, including between domestic and imported green ammonia. Further research will be required to understand the implications of such considerations at a grid/regional scale. Additional regional-specific considerations that might need to be addressed include whether a mismatch exists between low cost renewable supply and electricity demand (such as in Japan [5]), seasonality of renewable supply, the price of competing technologies (such as the low price of gas in the USA which favors CCS technologies [1] or hydrogen salt cavern potential in the UK [75]), the need for flexibility (as CCGT offers less flexibility than open cycle GT [76]), and, finally, policy decisions towards decarbonization and supporting different technological trajectories.

With growing interest in the use of green ammonia for decarbonizing fertilizer production [20] and shipping [14], experience with this energy vector will only increase. Given the consistent and predictable trends shown in other new clean technologies [67], such experience is likely to bring consistent cost reductions. Given the additional advantages that green ammonia-to-electricity production enjoys over other currently favored alternatives, such as nuclear and CCS, particularly in future VRE dominated grids with declining dispatchable capacity factor requirements, it clearly warrants serious attention as a clean fuel of the future.

Funding: This work was supported by the Economics of Energy Innovation and System Transition programme supported by UK BEIS International Climate Finance and Children's Investment Fund Foundation.

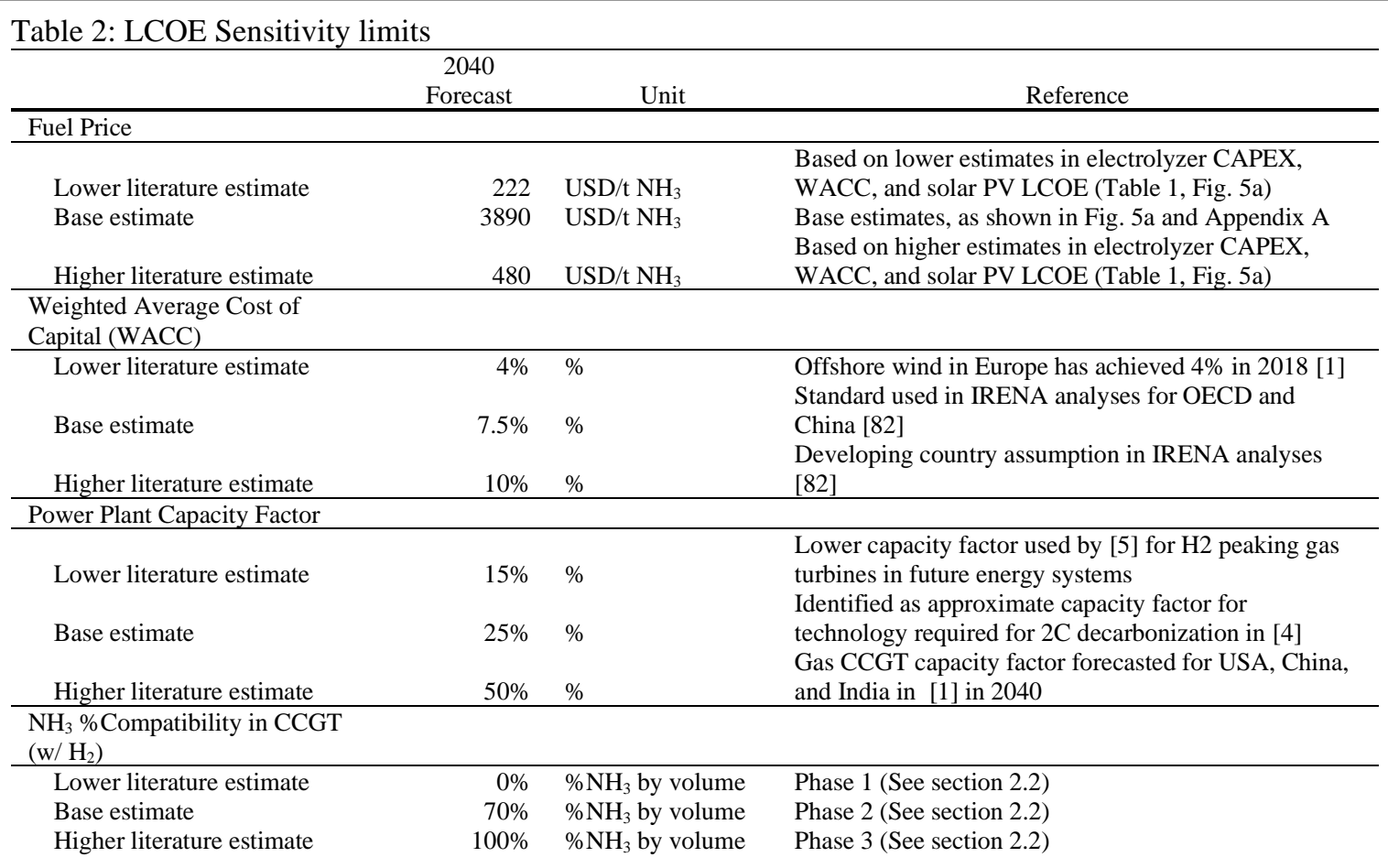




\section{Appendix A: Power-to-ammonia model and cost assumptions}

Table A1: Techno-economic assumptions for green ammonia production (base case)

\begin{tabular}{|c|c|c|c|c|c|c|c|}
\hline $\begin{array}{l}\text { Component Technical / } \\
\text { Economic Assumption }\end{array}$ & 2020 & 2025 & $\begin{array}{l}\text { Year } \\
2030\end{array}$ & 2035 & 2040 & $\begin{array}{c}\text { Unit } \\
\text { Note: } 2019 \text { USD }\end{array}$ & Reference \\
\hline \multicolumn{8}{|l|}{ Solar PV (single axis tracking) } \\
\hline Solar installed CAPEX & 576 & 493 & 410 & 386 & 363 & $\mathrm{USD}_{\mathrm{MW}} \mathrm{MW}_{\mathrm{p}, \mathrm{DC}}$ & DEA [41] \\
\hline $\begin{array}{l}\text { Global Horizontal Irradiance } \\
\text { (GHI) }\end{array}$ & 2,000 & 2,000 & 2,000 & 2,000 & 2,000 & $\mathrm{kWh} / \mathrm{m}^{2} / \mathrm{yr}$ & Global Solar Atlas [37] \\
\hline $\begin{array}{l}\text { Performance ratio (measure } \\
\text { of combined losses) }\end{array}$ & 0.86 & 0.91 & 0.95 & 0.96 & 0.96 & & DEA [41] \\
\hline $\begin{array}{l}\text { Capacity Factor (fixed tilt, } \\
\text { DC rating) }\end{array}$ & $20 \%$ & $21 \%$ & $22 \%$ & $22 \%$ & $22 \%$ & $\%$ & Calculated \\
\hline $\begin{array}{c}\text { DC/AC Sizing Factor (also } \\
\text { called Inverter Loading Ratio) }\end{array}$ & 1.25 & 1.25 & 1.25 & 1.25 & 1.25 & $\mathrm{~W}_{\mathrm{DC}} / \mathrm{W}_{\mathrm{AC}}$ & $\begin{array}{c}\text { DEA [41] and high insolation regions } \\
(>1,890 \mathrm{GHI}) \text { with single axis tracking } \\
\text { average } 1.28[38]\end{array}$ \\
\hline $\begin{array}{l}\text { Capacity Factor (fixed tilt, } \\
\text { AC rating) }\end{array}$ & $25 \%$ & $26 \%$ & $27 \%$ & $27 \%$ & $27 \%$ & $\%$ & $\begin{array}{l}\text { Calculated. Agrees with high insolation } \\
\text { regions in USA [38] }\end{array}$ \\
\hline $\begin{array}{l}\text { Single axis tracking increase } \\
\text { to capacity factor }\end{array}$ & $5 \%$ & $5 \%$ & $5 \%$ & $5 \%$ & $5 \%$ & $\%$ & $\begin{array}{l}\text { High insolation regions show up to } 5 \% \\
\text { point increase to capacity factor due to } \\
\text { single axis tracking [38] }\end{array}$ \\
\hline $\begin{array}{l}\text { Capacity Factor (single axis } \\
\text { tracking, AC rating) }\end{array}$ & $30 \%$ & $31 \%$ & $32 \%$ & $32 \%$ & $32 \%$ & $\%$ & $\begin{array}{c}\text { Calculated, and agrees with } 2018 \text { average } \\
\text { of } 30.4 \% \text { with range up to } 34 \% \text { in high } \\
\text { insolation regions in USA [38] }\end{array}$ \\
\hline $\begin{array}{l}\text { Solar single axis tracking } \\
\text { average annual full load hours } \\
\text { (AC rating) }\end{array}$ & 2,588 & 2,701 & 2,813 & 2,826 & 2,838 & $\mathrm{kWh} / \mathrm{yr} / \mathrm{kW}_{\mathrm{AC}}$ & Calculated \\
\hline O\&M & 7,400 & 6,800 & 6,200 & 5,950 & 5,700 & $\mathrm{USD}_{\mathrm{M}} \mathrm{MW}_{\mathrm{p}, \mathrm{DC}} / \mathrm{yr}$ & DEA [41] \\
\hline LCOE & 28.5 & 23.6 & 19.1 & 18.0 & 16.8 & USD/MWh & Calculated \\
\hline \multicolumn{8}{|l|}{ Electrolyzer } \\
\hline Electrolyzer CAPEX & 770 & 655 & 540 & 488 & 435 & USD/kW input & $\begin{array}{l}\text { IRENA } 2020 \text { Global Renewables Outlook } \\
\text { [93] }\end{array}$ \\
\hline Efficiency [LHV of H2] & $64 \%$ & $67 \%$ & $69 \%$ & $72 \%$ & $74 \%$ & $\%$ & IEA [5] \\
\hline $\mathrm{O} \& \mathrm{M}$ & $1.5 \%$ & $1.5 \%$ & $1.5 \%$ & $1.5 \%$ & $1.5 \%$ & $\%$ of CAPEX & IEA [5] \\
\hline $\begin{array}{l}\text { Stack Lifetime (operating } \\
\text { hours) }\end{array}$ & 95,000 & 95,000 & 95,000 & 100,000 & 100,000 & $\mathrm{hr}$ & IEA [5] \\
\hline \multicolumn{8}{|l|}{ Ammonia Synthesis } \\
\hline $\begin{array}{l}\text { Haber-Bosch CAPEX } \\
\text { Air Separation Unit (ASU) }\end{array}$ & 3,300 & 3,300 & 3,300 & 3,300 & 3,300 & USD/kg NH3/hr & {$[77]$} \\
\hline CAPEX & 1,450 & 1,450 & 1,450 & 1,450 & 1,450 & USD/kg N2/hr & {$[77]$} \\
\hline $\begin{array}{l}\text { Haber-Bosch electricity } \\
\text { consumption }\end{array}$ & 0.6 & 0.6 & 0.6 & 0.6 & 0.6 & $\mathrm{MWh} / \mathrm{t} \mathrm{NH} 3$ & {$[32]$} \\
\hline $\begin{array}{l}\text { ASU electricity } \\
\text { consumption }\end{array}$ & 0.119 & 0.119 & 0.119 & 0.119 & 0.119 & $\mathrm{MWh} / \mathrm{t} \mathrm{N} 2$ & {$[32]$} \\
\hline $\begin{array}{l}\mathrm{H}_{2} \text { Storage required for } \mathrm{HB} \\
\text { Management }\end{array}$ & 2.0 & 2.0 & 1.5 & 1.0 & 1.0 & days at full load & Modified from [29] \\
\hline \multicolumn{8}{|l|}{ Hydrogen Storage } \\
\hline $\begin{array}{l}\text { Aboveground ( } 200 \text { bar w/o } \\
\text { compressors) CAPEX }\end{array}$ & 1,050 & 961 & 872 & 743 & 615 & USD/kg & DEA [80] \\
\hline \multicolumn{8}{|l|}{ Lithium Ion Battery } \\
\hline $\begin{array}{l}\text { CAPEX (Energy } \\
\text { Component) } \\
\text { CAPEX (Power }\end{array}$ & 271 & 218 & 166 & 138 & 110 & $\mathrm{USD} / \mathrm{kWh}$ & DEA [80] \\
\hline Component) & 315 & 251 & 187 & 152 & 117 & $\mathrm{USD} / \mathrm{kW}$ & DEA [80] \\
\hline Fixed O\&M & 631 & 631 & 631 & 631 & 631 & USD/MW/yr & DEA [80] \\
\hline Variable O\&M & 2.3 & 2.2 & 2.1 & 2.0 & 2.0 & USD/MWh & DEA [80] \\
\hline \multicolumn{8}{|l|}{ Desalination } \\
\hline Installed CAPEX & 5.72 & 5.72 & 5.72 & 5.72 & 5.72 & $\mathrm{USD} / \mathrm{m}^{3} / \mathrm{yr}$ & $\begin{array}{l}\text { [87] assuming mechanical vapor } \\
\text { compression from [30] }\end{array}$ \\
\hline \multicolumn{8}{|l|}{ Financing } \\
\hline $\begin{array}{l}\text { Weighted Average Cost of } \\
\text { Capital (WACC) }\end{array}$ & $7.5 \%$ & $7.5 \%$ & $7.5 \%$ & $7.5 \%$ & $7.5 \%$ & $\%$ & IRENA [82] \\
\hline
\end{tabular}




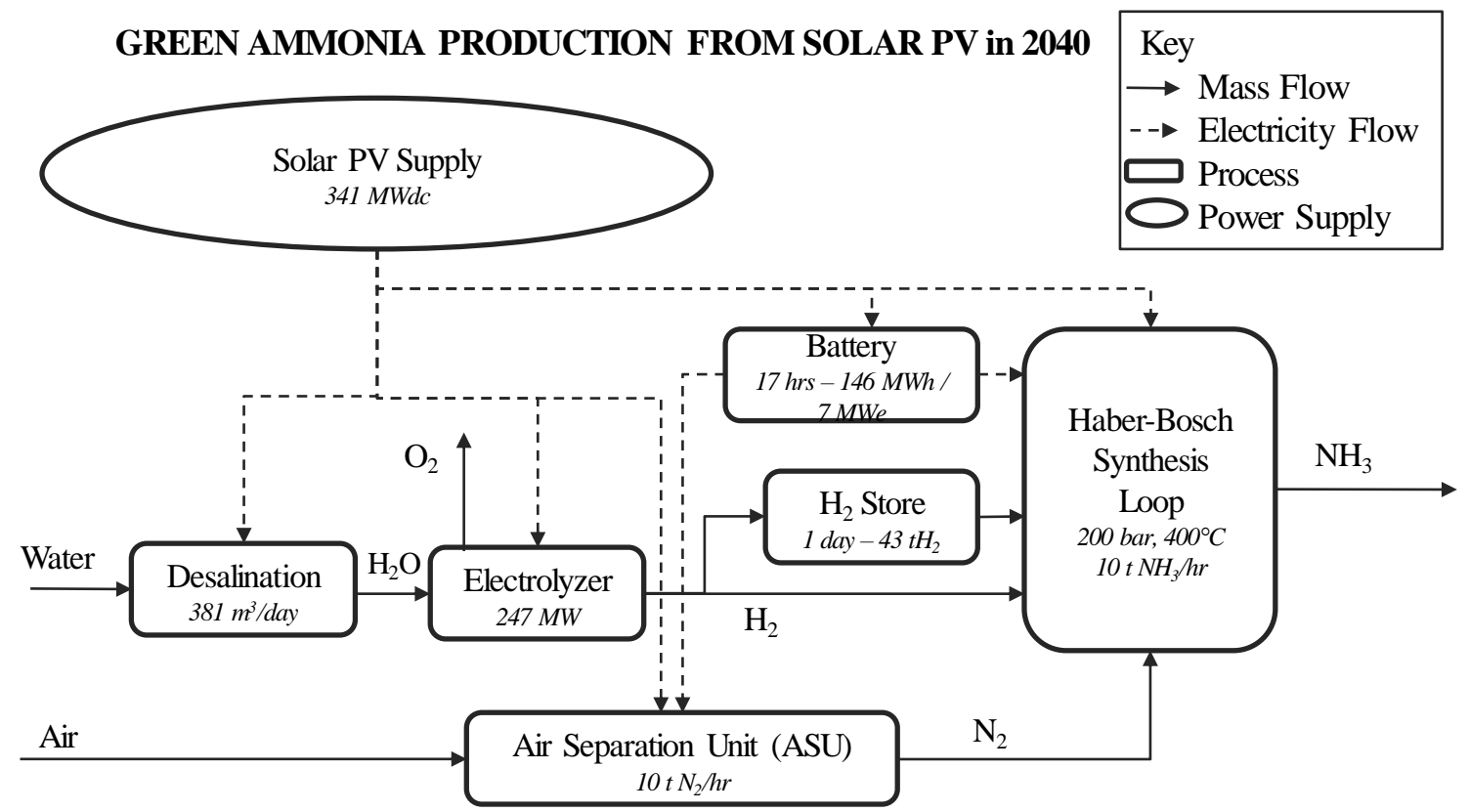

Figure A1: Diagram for solar PV, islanded green ammonia production plant in 2040

Table A2: Results of solar power to ammonia plant design for base case assumptions

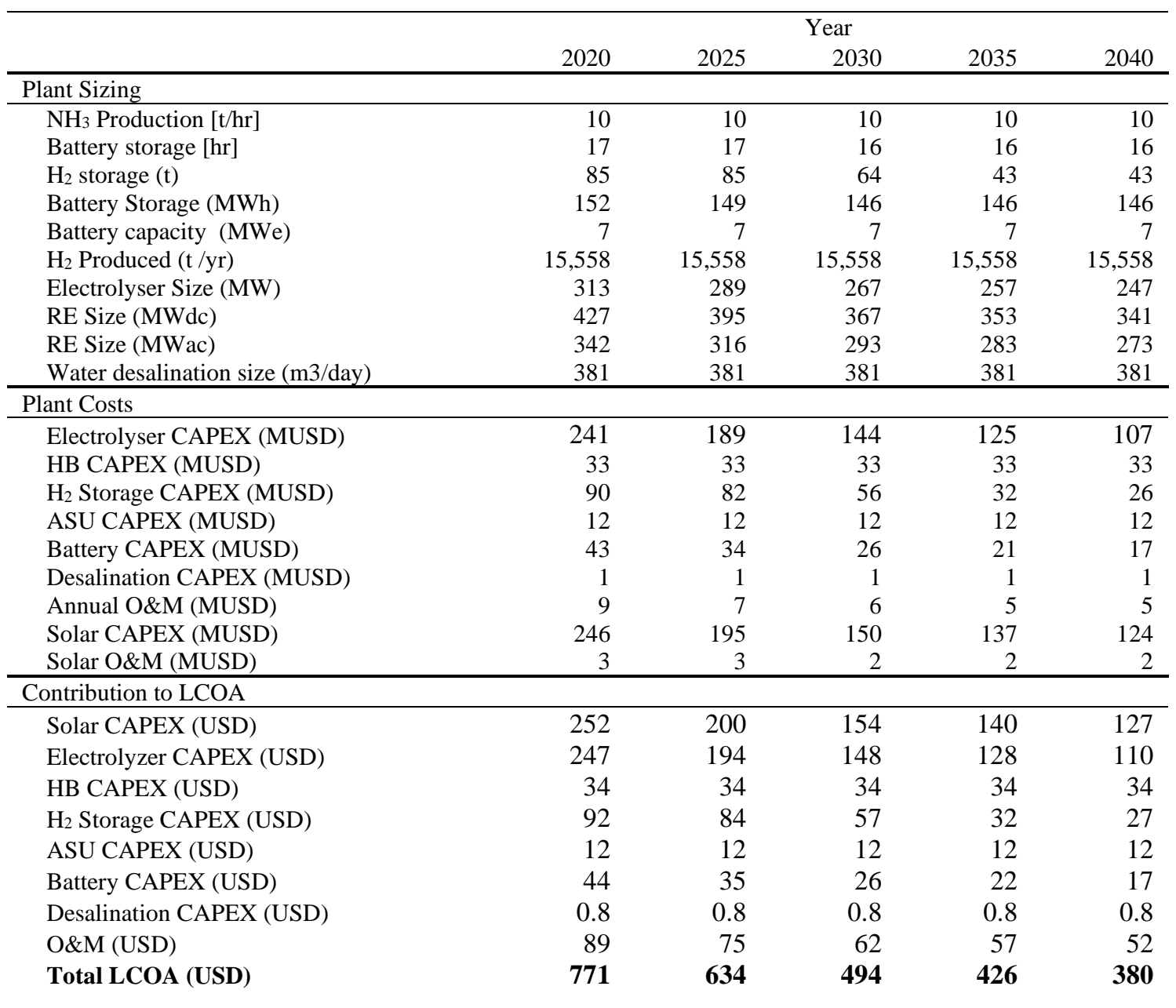




\section{Appendix B: Ammonia-to-power model}

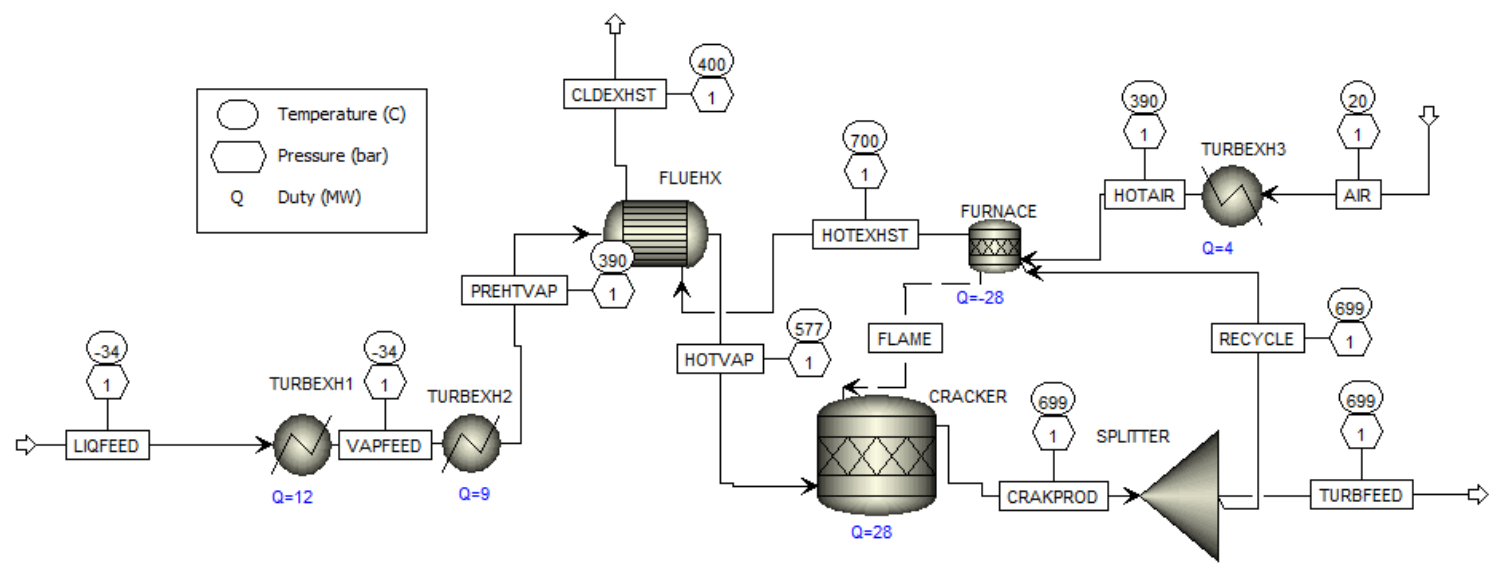

Fig B1. ASPEN Plus v9 model of ammonia decomposition reactor

Table B1: ASPEN Plus v9 modelling assumptions and results

\begin{tabular}{|c|c|c|c|}
\hline Key user defined variables & & Unit & Reference \\
\hline TURBFEED Flow Rate & 4.4 & $\mathrm{tH}_{2} / \mathrm{hr}$ & $\begin{array}{l}\text { Calculated based on Siemens } \\
\text { SGT800 } 82 \mathrm{MW} \text { CCGT } 1 \times 1 \\
\text { configuration, 60\% fuel } \\
\text { efficiency, assuming same fuel } \\
\text { efficiency for } \mathrm{H}_{2} \text { as natural gas } \\
{[92]}\end{array}$ \\
\hline CRACKER reactor conversion & $99 \%$ & $\%$ & $\begin{array}{l}\text { Based on cracking achieved in } \\
\text { small-scale commercial } \\
\text { ammonia decomposition } \\
\text { reactors }[54,55] .\end{array}$ \\
\hline CRACKER outlet temperature & 700 & $\mathrm{C}$ & $\begin{array}{l}\text { Literature suggests high } \\
\text { conversion cracking is } \\
\text { achievable between } 650{ }^{\circ} \mathrm{C} \\
\text { and } 900{ }^{\circ} \mathrm{C} \text { depending on the } \\
\text { catalyst [56] }\end{array}$ \\
\hline LIQFEED temperature & -34 & $\mathrm{C}$ & \\
\hline Excess air ratio & 1.12 & & \\
\hline \multicolumn{4}{|l|}{ Process Units } \\
\hline TURBEXH1, TURBEXH2, TURBEXH3 & \multirow{5}{*}{\multicolumn{3}{|c|}{$\begin{array}{l}\text { Heat exchangers modelled as heaters. Assuming heat from turbine } \\
\text { exhaust is } 400 \mathrm{C} \text { and Delta } \mathrm{T} \text { is } 10 \mathrm{C} \text {. } \\
\text { Heat exchanger. Delta } \mathrm{T} \text { min }=10 \mathrm{C} \text {. } \\
\text { Fired ammonia decomposition reactor modelled as } 2 \times \text { RGIBBS } \\
\text { reactors. CRACKER is ammonia decomposition reaction. } \\
\text { Fired ammonia decomposition reactor modelled as } 2 \times \text { RGIBBS } \\
\text { reactors. FURNACE is hydrogen and trace ammonia combustion } \\
\text { reaction } \\
\text { Separator to recycle some of ammonia decomposition reactor } \\
\text { products to fire the furnace. }\end{array}$}} \\
\hline FLUEHX & & & \\
\hline CRACKER & & & \\
\hline FURNACE & & & \\
\hline SPLITTER & & & \\
\hline \multicolumn{4}{|l|}{ Required Convergence } \\
\hline SPLITTER & \multirow{2}{*}{\multicolumn{3}{|c|}{$\begin{array}{l}\text { Recycle stream size converged to satisfy ammonia decomposition } \\
\text { reactor constraints } \\
\text { Liquid ammonia feed mass flow rate converged to satisfy } \\
\text { constraints of system output to gas turbine }\end{array}$}} \\
\hline LIQFEED & & & \\
\hline
\end{tabular}

Results

SPLITTER recycle \%

$20.5 \% \%$ 


\section{Appendix C: LCOE Assumptions}

Table C1: LCOE Techno-economic Assumptions

\begin{tabular}{|c|c|c|c|}
\hline & & Unit & Reference \\
\hline \multicolumn{4}{|l|}{ General assumptions } \\
\hline \multirow[t]{2}{*}{ Plant size } & 1,000 & MW & UK BEIS \& Uniper [71] \\
\hline & & & Identified as approximate capacity factor for technology \\
\hline \multirow[b]{2}{*}{ WACC } & $25 \%$ & $\%$ & required for $2^{\circ} \mathrm{C}$ decarbonization in [4] \\
\hline & $7.5 \%$ & $\%$ & Standard used in IRENA for OECD and China [82] \\
\hline $\mathrm{CO}_{2}$ Price & 140 & $\mathrm{USD} / \mathrm{t} \mathrm{CO}_{2}$ & $\begin{array}{l}\text { IEA advanced economies power sector forecasted } \mathrm{CO}_{2} \text { price in } \\
2040[1]\end{array}$ \\
\hline \multicolumn{4}{|l|}{ Fuel Price in 2040} \\
\hline Natural Gas & 8.9 & USD/MMBTU & EU price forecast 2040 in IEA STEPS scenario [1] \\
\hline Coal & 78 & $\mathrm{USD} / \mathrm{t}$ & EU price forecast 2040 in IEA STEPS scenario [1] \\
\hline Green Ammonia & 380 & $\mathrm{USD} / \mathrm{t} \mathrm{NH}_{3}$ & Figure $5 \mathrm{a}$ \\
\hline Biomass & 8.0 & USD/GJ & ESME for Biomass imports mid-range 2050 [90] \\
\hline \multicolumn{4}{|l|}{ Coal + CCS } \\
\hline Supercritical plant fuel efficiency (LHV) & $41 \%$ & $\%$ & $\begin{array}{l}\text { Global CCS Institute [84] } \\
\text { Global CCS Institute [84]. No future progress assumed on }\end{array}$ \\
\hline CAPEX & 2,328 & $\mathrm{USD} / \mathrm{kW}$ & Rankine cycle CAPEX or efficiency, in line with IEA [1] \\
\hline Economic Lifetime & 30 & years & {$[90]$} \\
\hline Plant fuel efficiency with CCS (LHV) & $33 \%$ & $\%$ & Global CCS Institute [84] \\
\hline CCS additional CAPEX & 1,426 & USD/kW & Global CCS Institute [84] \\
\hline Fixed O\&M with CCS & 64,912 & USD/MW/yr & Global CCS Institute [84] \\
\hline Variable O\&M with CCS & 19 & USD/MWh & Global CCS Institute [84] \\
\hline Lifecycle emissions before CCS & 797 & $\mathrm{~kg} \mathrm{CO}_{2} / \mathrm{MWh}$ & $\begin{array}{l}\left.\text { Average of Global CCS Institute [84] (774 } \mathrm{kg} \mathrm{CO}_{2} / \mathrm{MWh}\right) \text { and } \\
\text { IPCC [74] (820 kg CO} / \mathrm{MWh}) \\
\left.\text { Average of Global CCS Institute [84] (97 } \mathrm{kg} \mathrm{CO}_{2} / \mathrm{MWh}\right) \text { and }\end{array}$ \\
\hline \multicolumn{4}{|l|}{ Gas CCGT + CCS } \\
\hline CCGT plant fuel efficiency (LHV) & $60 \%$ & $\%$ & $\begin{array}{l}\text { UK BEIS \& Uniper [71]. No future progress assumed on GT } \\
\text { CAPEX or efficiency, in line with IEA [1] } \\
\text { UK BEIS \& Uniper [71]. No future progress assumed on GT }\end{array}$ \\
\hline CAPEX & 766 & $\mathrm{USD} / \mathrm{kW}$ & CAPEX or efficiency, in line with IEA [1] \\
\hline Lifetime & 25 & years & UK BEIS \& Uniper [71] \\
\hline Plant fuel efficiency with CCS (LHV) & $53 \%$ & $\%$ & UK BEIS \& Uniper [71] \\
\hline CCS additional CAPEX & 1116 & $\mathrm{USD} / \mathrm{kW}$ & UK BEIS \& Uniper [71] \\
\hline Fixed O\&M with CCS & 42,225 & USD/MW/yr & UK BEIS \& Uniper [71] \\
\hline Variable O\&M with CCS & 11 & USD/MWh & UK BEIS \& Uniper [71] \\
\hline Lifecycle emissions before CCS & 490 & $\mathrm{~kg} \mathrm{CO}_{2} / \mathrm{MWh}$ & IPCC [74] including methane emissions $\mathrm{CO}_{2}$ equivalent \\
\hline Lifecycle missions after CCS & 170 & $\mathrm{~kg} \mathrm{CO}_{2} / \mathrm{MWh}$ & IPCC [74] including methane emissions $\mathrm{CO}_{2}$ equivalent. \\
\hline CCS CAPEX reductions in future & $30 \%$ & $\%$ & UK BEIS \& Uniper [71] \\
\hline Lifecycle emissions after CCS in future & 94 & $\mathrm{~kg} \mathrm{CO}_{2} / \mathrm{MWh}$ & $\begin{array}{l}\text { IPCC [74] minimum range of estimates for present day } \\
\text { technology, including methane emissions } \mathrm{CO}_{2} \text { equivalent. }\end{array}$ \\
\hline \multicolumn{4}{|l|}{ Ammonia CCGT } \\
\hline CCGT plant fuel efficiency (LHV) & $60 \%$ & $\%$ & Assuming same as NG [71] \\
\hline CAPEX & 766 & $\mathrm{USD} / \mathrm{kW}$ & Assuming same as NG [71] \\
\hline Lifetime & 25 & years & Assuming same as NG [71] \\
\hline Fixed O\&M & 17,353 & USD/MW/yr & Assuming same as NG [71] \\
\hline Variable O\&M & 5 & USD/MWh & Assuming same as NG [71] \\
\hline \multicolumn{4}{|l|}{ Ammonia CCGT with Cracker } \\
\hline \multirow{2}{*}{$\begin{array}{l}\text { Cracker conversion } \\
\text { Cracker output recycle size }\end{array}$} & $99 \%$ & $\%$ of $\mathrm{NH}_{3}$ & $\begin{array}{l}99 \% \text { conversion at } 850^{\circ} \mathrm{C} \text { based on small-scale commercial } \\
\text { crackers using nickel catalysts [54] [55].. }\end{array}$ \\
\hline & $20.5 \%$ & $\%$ of output & Calculated using ASPEN Plus \\
\hline $\begin{array}{l}\mathrm{H}_{2} \text { separation losses } \\
\text { Phase } 1\end{array}$ & $1 \%$ & $\%$ & $\begin{array}{l}\text { Based on } 80-85 \% \text { recovery via } \mathrm{H} 2 \text { membrane }[79] \text { and tail gas } \\
\text { used for recycle, so very small losses }\end{array}$ \\
\hline Phase 1 & & & \\
\hline$\overline{\text { Cracker size }}$ & 63.7 & ton $\mathrm{H}_{2} / \mathrm{hr}$ & Calculated using ASPEN Plus \\
\hline Plant fuel efficiency with cracker (LHV) & $53.8 \%$ & $\%$ & Calculated using ASPEN Plus \\
\hline Cracker additional CAPEX & 402 & USD/kW & Calculated using Cracker cost curve from Figure 4 \\
\hline Phase 2 & & & \\
\hline$\overline{\text { Cracker size }}$ & 17.3 & ton $\mathrm{H}_{2} / \mathrm{hr}$ & Calculated using ASPEN Plus \\
\hline Plant fuel efficiency with cracker (LHV) & $58.0 \%$ & $\%$ & Calculated using ASPEN Plus \\
\hline Cracker additional CAPEX & 152 & $\mathrm{USD} / \mathrm{kW}$ & Calculated using Cracker cost curve from Figure 4 \\
\hline Nuclear & & & \\
\hline Fuel Cost & 4 & USD/MWh & World Nuclear Association [89] \\
\hline CAPEX & 4,500 & $\mathrm{USD} / \mathrm{kW}$ & EU CAPEX in IEA's 2040 forecast [1] \\
\hline Economic Lifetime & 30 & years & [90] \\
\hline Fixed O\&M & 100,000 & $\mathrm{USD} / \mathrm{MW} / \mathrm{yr}$ & EIA [88] \\
\hline Bioenergy with CCS & & & \\
\hline BECCS plant fuel efficiency (LHV) & $37 \%$ & $\%$ & ESME- biomass-dedicated steam turbine power station [90] \\
\hline CAPEX & 3,653 & $\mathrm{USD} / \mathrm{kW}$ & ESME [90] \\
\hline Lifetime & 30 & years & ESME [90] \\
\hline Fixed O\&M with CCS & 140,492 & USD/MW/yr & ESME [90] \\
\hline Variable O\&M with CCS & 7 & USD/MWh & ESME [90] \\
\hline Negative $\mathrm{CO} 2$ emissions & 0.35 & $\mathrm{GtCO}_{2} / \mathrm{EJ}$ & Mean value from Fuss et al range of $0.02-0.05 \mathrm{GtCO}_{2} / \mathrm{EJ}$ [73] \\
\hline Negative $\mathrm{CO} 2$ emissions (electricity) & 342 & $\mathrm{~kg} \mathrm{CO}_{2} / \mathrm{MWh}$ & Calculated based on $37 \%$ efficiency \\
\hline
\end{tabular}




\section{References}

[1] IEA, "World Energy Outlook 2019," IEA, Paris, 2019.

[2] IRENA, "Hydrogen: A renewable energy perspective," International Renewable Energy Agency, Abu Dhabi, 2019.

[3] N. A. Sepulveda, J. D. Jenkins, F. J. de Sisternes and R. K. Lester, "The Role of Firm Low-Carbon Electricity Resources in Deep Decarbonization of Power Generation," Joule, p. 2403-2420, 2018.

[4] BNEF, "New Energy Outlook (NEO)," Bloomberg New Energy Finance, 2019.

[5] IEA, "The Future of Hydrogen: Seizing today’s opportunities," International Energy Agency, 2019.

[6] BNEF, "Hydrogen Economy Outlook - Key Messages," Bloomberg New Energy Finance, 2020.

[7] The Royal Society, "Ammonia: zero-carbon fertiliser, fuel and energy store," London, 2020.

[8] Z. Cesaro, I. Wilkinson and A. Eisfelder, "Power-to-X: A Closer Look at E-ammonia," Siemens Energy, 2020.

[9] MAN Energy Solutions, "Engineering the future two-stroke green-ammonia engine," Copenhagen, 2019.

[10] C. Smith, A. K. Hill and L. Torrente-Murciano, "Current and future role of Haber-Bosch ammonia in a carbon-free energy landscape," Energy Environ. Sci, pp. 331-344, 2020.

[11] I. I. Cheema and U. Krewer, "Operating envelope of Haber-Bosch process design for power-to-ammonia," RSC Advances, vol. 8, no. 61, pp. 34926-34936, 2018.

[12] A. Valera-Medina, H. Xiao, M. Owen-Jones, W. David and P. Bowen, "Ammonia for power," Progress in Energy and Combustion Science, pp. 63-102, 2018.

[13] Y. Zhao, B. P. Setzler, J. Wang, J. Nash, T. Wang, B. Xu and Y. Yan, "An Efficient Direct Ammonia Fuel Cell for Affordable CarbonNeutral Transportation," Joule, no. 3, p. 24722484, 2019.

[14] N. Ash and T. Scarbrough, "Sailing on solar: Could green ammonia decarbonise international shipping?," Environmental Defense Fund, London, 2019.

[15] Lloyd's Register (LR) \& University Maritime Advisory Services (UMAS), "Zero Emission Vessels (ZEV): Transition Pathways," 2019.
[16] Korean Register (KR), "Forecasting the Alternative Marine Fuel: Ammonia," KR, 2019.

[17] DNV-GL, "Maritime Forecast to 2050: Energy Transition Outlook 2019," 2019.

[18] R. Carlo, B. J. Marc, S. de la Fuente Santiago, T. Smith and K. Søgaard, "Aggregate investment for the decarbonisation of the shipping industry," UMAS, 2020.

[19] Wärtsilä Corporation, "Wärtsilä advances future fuel capabilities with first ammonia tests," 25 March 2020. [Online]. Available: https://www.wartsila.com/media/news/25-032020-wartsila-advances-future-fuel-capabilitieswith-first-ammonia-tests-2670619. [Accessed April 2020].

[20] Yara, "Yara and Nel collaborate to produce carbon free hydrogen for fertilizer production," Yara, 20 August 2019. [Online]. Available: https://www.yara.com/news-andmedia/news/archive/2019/yara-and-nel-carbonfree-hydrogen-for-fertilizer-production/. [Accessed 13 Oct 2019].

[21] AirProducts, "Air Products, ACWA Power and NEOM Sign Agreement for \$5 Billion Production Facility in NEOM Powered by Renewable Energy for Production and Export of Green Hydrogen to Global Markets," AirProducts News Release, 7 July 2020. [Online]. Available: http://www.airproducts.com/Company/newscenter/2020/07/0707-air-products-agreementfor-green-ammonia-production-facility-forexport-to-hydrogen-market.aspx.

[22] Enaex, "ENAEX \& ENGIE: On the path to a smooth zero carbon transition in the Chilean Mining Sector," ENAEX, 11 July 2019. [Online]. Available: https://www.enaex.com/en/enaex-engie-on-thepath-to-a-smooth-zero-carbon-transition-in-thechilean-mining-sector/. [Accessed 13 October 2019].

[23] Balance Co, "Kapuni 'green' hydrogen project seen as catalyst for NZ market," Ballance AgriNutrients, 20 June 2019. [Online]. Available: https://ballance.co.nz/Kapuni-hydrogen-project. [Accessed 13 Oct 2019].

[24] BP, "bp Australia announces feasibility study into hydrogen energy production facility," 08 May 2020. [Online]. Available: https://www.bp.com/en/global/corporate/newsand-insights/press-releases/bp-australiaannounces-feasibility-study-into-hydrogenenergy-production-facility.html.

[25] Goverment of South Australia, "Hydrogen and green ammonia production facility," 2018. [Online].

Available: http://www.renewablessa.sa.gov.au/topic/hydro gen/hydrogen-projects/hydrogen-green- 
ammonia-production-facility. [Accessed 21 August 2019].

[26] Queensland Government, "Eye on Gladstone for proposed gigawatt-scale green hydrogen and ammonia development, The Honourable Cameron Dick: Minister for State Development, Manufacturing, Infrastructure and Planning," Queensland Government, 27 Feb 2020. [Online]. Available:

http://statements.qld.gov.au/Statement/2020/2/2 7/eye-on-gladstone-for-proposed-gigawattscalegreen-hydrogen-and-ammonia-development. [Accessed 20 Mar 2020].

[27] ARENA, "Queensland green ammonia plant could use renewable hydrogen," Australian Renewable Energy Agency, 30 Sep 2019. [Online]. Available: https://arena.gov.au/news/queensland-greenammonia-plant-could-use-renewablehydrogen/. [Accessed 13 Oct 2019].

[28] R. M. Nayak-Luke and R. Banares-Alcantara, "Techno-economic viability of islanded green ammonia as a carbon-free energy vector and as a substitute for conventional production," Energy \& Environmental Science, 2020.

[29] J. Armijo and C. Philibert, "Flexible production of green hydrogen and ammonia from variable solar and wind energy: Case study of Chile and Argentina," International Journal of Hydrogen Energy, pp. 1541-1558, 2020.

[30] E. Morgan, "Techno-economic feasibility study of ammonia plants powered by offshore wind," University of Massachussetts Amherst, Dept of Mechanical and Industrial Engineering, 2013.

[31] S. S. Beerbühl, M. Fröhling and F. Schultmann, "Combined scheduling and capacity planning of electricity-based," European Journal of Operational Research, vol. 241, pp. 851-862, 2014.

[32] R. Nayak-Luke, R. Banares-Alcantara and I. Wilkinson, "'Green" Ammonia: Impact of Renewable Energy Intermittency on Plant Sizing and Levelized Cost of Ammonia," Industrial and Engineering Chemistry Research, no. 57, p. 14607-14616, 2018.

[33] T. Ito, H. Ishii, J. Zhang, S. Ishihara and T. Suda, "New Technology of the Ammonia Co-Firing with Pulverized Coal to Reduce the NOx Emission," in AIChE Annual Meeting, Orlando, FL, USA, 2019.

[34] A. Valera-Medina, M. Gutesa, H. Xiao, D. Pugh, A. Giles, B. Goktepe, R. Marsh and P. Bowen, "Premixed ammonia/hydrogen swirl combustion under rich fuel conditions for gas turbines operation," International Journal of Hydrogen Energy, vol. 44, no. 16, pp. 8615-8626, 2019.
[35] A. T. Wijayanta, T. Oda, C. W. Purnomo, T. Kashiwagi and M. Aziz, "Liquid hydrogen, methylcyclohexane, and ammonia as potential hydrogen storage: Comparison review," International Journal of Hydrogen Energy, pp. 15026-15044, 2019.

[36] R. Bañares-Alcantara, G. I. Dericks, M. Fiaschetti, P.' Grünewald, J. M. Lopez, A. Yang, L. Ye and S. Zhao, "Analysis of Islanded-Based Energy Storage Systems," University of Oxford, Oxford, UK, 2015.

[37] The World Bank Group, "Global Solar Atlas," Solargis s.r.o. ("Solargis") on behalf of the World Bank Group ("World Bank Group"), Feb 2020. [Online]. Available: https://globalsolaratlas.info/. [Accessed June 2020].

[38] M. Bolinger, J. Seel and D. Robson, "UtilityScale Solar: Empirical Trends in Project Technology, Cost, Performance, and PPA Pricing in the United States - 2019 Edition," Lawrence Berkeley National Laboratory, 2019.

[39] C. SA.USA Patent Ammonia Casale SA, Method for Load Regulation of an Ammonia Plant, US Patent 9,463,983 B2, 2016.

[40] European Fuel Cells and Hydrogen Joint Undertaking (FCH JU), "Major project to convert offshore vessel to run on ammoniapowered fuel cell," Jan 2020. [Online]. Available:

https://www.fch.europa.eu/sites/default/files/Pr ess \%20release \%20ShipFC\%20project\%20\%28 004\%29.pdf.

[41] Danish Energy Agency, "Technology Data for Generation of Electricity and District Heating," Copenhagen, 2020.

[42] Z. Cesaro, J. Thatcher and R. Banares-Alcantara, "Chapter 9: Techno-economic aspects of the use of ammonia as energy vector," in Technoeconomic Challenges of Green Ammonia as Energy Vector (in production), 2020.

[43] Institute for Sustainable Process Technology (ISPT), "Power to ammonia," 2016.

[44] Equinor Energy AS and H. S. A. K. I. ANDERSEN, "AMMONIA CRACKING". AU2016398360A1;CA3017460A1;CN1088847 61A;EP3430251A1;EP3430251A4;WO201716 0154A1;US2019084831A1 23 Jan 2019.

[45] O. Kurata, N. Iki, T. Inoue, T. Matsunuma, T. Tsujimura, H. Furutani, M. Kawano, K. Arai, E. C. Okafor, A. Hayakawa and H. Kobayashi, "Development of a wide range-operable, richlean low-NOx combustor for NH3 fuel gasturbine power generation," Proceedings of the Combustion Institute, pp. 4587-4595, 2019.

[46] "Our Committments: Power the EU," EUTurbines, 2019. 
[47] Siemens Gas and Power, "HYFLEXPOWER: The world's first integrated power-to-X-topower hydrogen gas turbine demonstrator," 29 May 2020. [Online]. Available: https://press.siemens.com/global/en/pressreleas e/hyflexpower-worlds-first-integrated-power-xpower-hydrogen-gas-turbine-demonstrator.

[48] Mitsubishi Hitachi Power Systems, "Intermountain Power Agency Orders MHPS JAC Gas Turbine Technology for RenewableHydrogen Energy Hub," 10 March 2020. [Online]. Available: https://amer.mhps.com/intermountain-poweragency-orders-mhps-jac-gas-turbinetechnology-for-renewable-hydrogen-energyhub.html.

[49] ETN Global, " The Path Towards a Zero-Carbon Gas Turbine," European Turbine Network, 2020.

[50] M. Božo Guteša, M. Vigueras-Zuniga, M. Buffi, T. Seljak and A. Valera-Medina, "Fuel rich ammonia-hydrogen injection for humidified gas turbines," Applied Energy, p. 113334, 2019.

[51] A. Valera-Medina, R. Marsh, J. Runyon, D. Pugh, P. Beasley, T. Hughes and P. Bowena, "Ammonia-methane combustion in tangential swirl burners for gas turbine power generation," Applied Energy, pp. 1362-1371, 2017.

[52] G. Sorrentino, P. Sabia, P. Bozza, R. Ragucci and M. de Joannon, "Low-NOx conversion of pure ammonia in a cyclonic burner under locally diluted and preheated conditions," Applied Energy, p. 113676, 2019.

[53] Siemens Gas and Power, "Hydrogen power with Siemens gas turbines," 2020.

[54] "Lindberg HYAM® Ammonia Dissociator," Lindberg/MPH, 2020. [Online]. Available: https://www.lindbergmph.com/heat-treatfurnaces/atmosphere-generators/lindberg-hyamammonia-dissociator. [Accessed Jan 2020].

[55] SAM Gas Projects, "Ammonia Cracker," 2020. [Online]. Available: https://www.psanitrogen.com/ammonia-cracker.html. [Accessed Jan 2020].

[56] J. W. Makepeace, T. J. Wood, H. M. A. Hunter, M. O. Jones and W. I. F. David, "Ammonia decomposition catalysis using nonstoichiometric lithium imide," Chemical Science, no. 7, pp. 3805-3815, 2015.

[57] R. Nasharuddin, M. Zhu, Z. Zhang and D. Zhang, "A technoeconomic analysis of centralised and distributed processes of ammonia dissociation to hydrogen for fuel cell vehicle applications," International Journal of Hydrogen Energy, no. 44, pp. 14445-14455, 2019.

[58] GasBarre, "Ammonia Dissociators: C.I. Hayes ADG Series," 2020. [Online]. Available: https://www.gasbarre.com/products/auxiliaryequipment/furnace-auxiliary-equipment/.

[Accessed 1 June 2020].

[59] J. Mays, "One Step Hydrogen Generation Through Sorption Enhanced Reforming," U.S. DOE Advanced Manufacturing Office Program Review Meeting, Washington, D.C., 2015.

[60] R. Elshout, "Hydrogen Production by Steam Reforming," Chemical Engineering, May 2010.

[61] N. d. Vries, "Safe and effective application of ammonia as a marine fuel," C-Job \& Partners B.V., TUDelft, 2019.

[62] J. M. Ogden, "REVIEW OF SMALL STATIONARY REFORMERS FOR HYDROGEN PRODUCTION," Alternative Fuels Data Center, US Dept of Energy, 2001.

[63] NREL, "H2A: Hydrogen Analysis Production Models," NREL, 2018. [Online]. Available: https://www.nrel.gov/hydrogen/h2a-productionmodels.html. [Accessed 02 Feb 2020].

[64] "Engineering the future two-stroke greenammonia engine," MAN Energy Solutions, Copenhagen, 2019.

[65] IRENA, "Resource: Data Methodology," International Renewable Energy Agency, 2016.

[66] S. Samadi, "The experience curve theory and its application in the field of electricity generation technologies - A literature review," Renewable and Sustainable Energy Reviews, pp. 23462364, 2018.

[67] J. D. Farmer and F. Lafond, "How Predictable Is Technological Progress?," Research Policy, vol. 45, no. 3, p. 647-65, 2016.

[68] S. Krishnan, M. Fairlie, P. Andres, T. de Groot and G. J. Kramer, "Chapter 10 - Power to gas (H2): alkaline electrolysis," in Technological Learning in the Transition to a Low-Carbon Energy System, Academic Press, 2020, pp. 165187.

[69] Wood Mackenzie, "Green hydrogen production: Landscape, projects and costs," 2019.

[70] Wood Mackenzie, "Green hydrogen pipeline more than doubles in five months," 07 April 2020. [Online]. Available: https://www.woodmac.com/ourexpertise/focus/transition/green-hydrogenpipelinesoars/?utm_source=gtm\&utm_medium $=$ article \&utm_campaign=wmpr_greenhydrogen. [Accessed 17 June 2020].

[71] C. B. \&. A. Read, "BEIS: CCUS TECHNICAL ADVISORY - REPORT ON ASSUMPTIONS," BUSINESS ENERGY \& INDUSTRIAL STRATEGY, UNIPER Technologies, London, 2018. 
[72] M. Fajardy and N. M. Dowell, "The energy return on investment of BECCS: is BECCS a threat to energy security?," Energy Environ. Sci, vol. 11, pp. 1581--1594, 2018.

[73] S. Fuss and et al, "Negative emissions-Part 2: Costs, potentials and side effects," Environ. Res. Lett, vol. 13, p. 063002, 2018.

[74] T. Bruckner, I. Bashmakov, Y. Mulugetta, H. Chum, A. d. 1. V. Navarro, J. Edmonds, A. Faaij, B. Fungtammasan, A. Garg, E. Hertwich, D. Honnery, D. Infield, M. Kainuma, S. Khennas, S. Kim, H. Nimir, K. Riahi, N. Strachan, R. Wiser and X. Zhang, "Chapter 7: Energy Systems," in Climate Change 2014: Mitigation of Climate Change. Contribution of Working Group III to the Fifth Assessment Report of the Intergovernmental Panel on Climate Change, Cambridge University Press, 2014.

[75] Element Energy Ltd, "Hydrogen supply chain evidence base," Prepared by Element Energy Ltd for the UK Department for Business, Energy \& Industrial Strategy (BEIS), London, 2018.

[76] IRENA, "Innovation landscape brief: Flexibility in conventional power plants," International Renewable Energy Agency (IRENA), Abu Dhabi, 2019.

[77] J. Ikaheimo, J. Kiviluoma, R. Weiss and H. Holttinen, "Power-to-ammonia in future North European $100 \%$ renewable power and heat system," International Journal of Hydrogen Energy, vol. 43, pp. 17295-17308, 2018.

[78] W. Mathis and J. Thornhill, "Hydrogen's Plunging Price Boosts Role as Climate Solution," BloombergNEF, 21 August 2019.

[79] S. Giddey, S. P. S. Badwal, C. Munnings and M. Dolan, "Ammonia as a Renewable Energy Transportation Media," ACS Sustainable Chemistry \& Eng., vol. 5, 2017.

[80] Danish Energy Agency and Energinet, "Technology Data for Energy Storage," 2020.

[81] "Technology Data for Energy Storage," Danish Energy Agency and Energinet, 2019.

[82] IRENA, "Renewable Power Generation Costs in 2018," International Renewable Energy Agency (IRENA), Abu Dhabi, 2019.

[83] Danish Energy Agency, "Technology Data for the Indonesian Power Sector: Catalogue for Generation and Storage of Electricity," Danish Energy Agency and Indonesian National Energy Council, December 2017.

[84] L. Irlam, "Global Costs of Carbon Capture and Storage," Global CCS Institute, 2017.

[85] M. J. Palys and P. Daoutidis, "Using hydrogen and ammonia for renewable energy storage: A geographically comprehensive techno-economic study," Computers and Chemical Engineering, 2020 .
[86] Nutrien, "Nutrien Fact Book 2019," 2019.

[87] M. A. Jamil and S. M. Zubair, "On thermoeconomic analysis of a single-effect mechanical vapor compression desalination system," Desalination, vol. 420, pp. 292-307, 2017.

[88] U.S. Energy Information Administration (EIA), "Capital Cost Estimates for Utility Scale Electricity Generating Plants," Department of Energy, 2016.

[89] World Nuclear Association, "Economics of Nuclear Power," 2020.

[90] Energy Systems Catapult, "ESME v4.4," Energy Technologies Institute (ETI), UK, 2018.

[91] IRENA, "Future of Solar Photovoltaic: Deployment, investment, technology, grid integration and socio-economic aspects," International Renewable Energy Agency, Abu Dhabi, 2019.

[92] "SGT-800 industrial gas turbine: Technical Data," Siemens, [Online]. Available: https://new.siemens.com/global/en/products/ene rgy/power-generation/gas-turbines/sgt800.html. [Accessed 30 July 2019].

[93] IRENA, "Global Renewables Outlook: Energy transformation 2050," International Renewable Energy Agency (IRENA), 2020. 